\title{
Digital outcrop modelling using "structure-from- motion" photogrammetry: Acquisition strategies, validation and interpretations to different sedimentary environments
}

\author{
Andrés Bilmes $^{\mathrm{a}, *}$, Leandro D'Elia ${ }^{\mathrm{b}}$, Luciano Lopez ${ }^{\mathrm{c}}$, Sebastián Richiano ${ }^{\mathrm{a}}$, Augusto Varela ${ }^{\mathrm{d}, \mathrm{e}}$, \\ María del Pilar Alvarez ${ }^{\mathrm{f}}$, Joaquín Bucher ${ }^{\mathrm{b}}$, Inés Eymard ${ }^{\mathrm{g}}$, Martín Muravchik ${ }^{\mathrm{h}}$, Juan Franzese ${ }^{\mathrm{b}}$, \\ Daniel Ariztegui ${ }^{\mathrm{g}}$ \\ ${ }^{a}$ Instituto de Geología y Paleontología (CONICET-CENPAT), Boulevard Almirante Brown 2915, ZC: U9120ACD, Puerto Madryn, Chubut, Argentina \\ ${ }^{\mathrm{b}}$ Centro de Investigaciones Geológicas (CIG), Universidad Nacional de La Plata - CONICET, La Plata, Argentina \\ ${ }^{\mathrm{c}}$ Instituto de Recursos Minerales (UNLP), La Plata, Argentina \\ ${ }^{\mathrm{d}}$ Cátedra de Micromorfología de Suelos, Facultad de Ciencias Naturales y Museo, Calle 122 y $60 \mathrm{~s} / \mathrm{n}$ (1900), La Plata, Argentina \\ ${ }^{\text {e }}$ Y-TEC S.A, Av. del Petróleo s/n (1923), Berisso, Argentina and Consejo Nacional de Investigaciones Científicas y Técnicas CONICET, Argentina \\ f IPEEC (CONICET-CENPAT), Puerto Madryn, Chubut, Argentina \\ ${ }^{\mathrm{g}}$ University of Geneva, Earth Science Department, Switzerland \\ ${ }^{\mathrm{h}}$ Department of Earth Science, University of Bergen, Bergen, Norway
}

A R T I C L E I N F O

\section{Keywords:}

Virtual outcrops

High-resolution digital terrain models

Acquisition

Validation

Virtual analysis

\begin{abstract}
A B S T R A C T
Structure from Motion-Multi-View Stereo (SfM-MVS) is a relatively new technique that is being adopted in the analysis of sedimentary systems. The technique is especially applicable to studies which focus on the distribution, geometry and quantification of geological bodies including the analysis of sedimentary forms and tectonic structures. This photogrammetric method allows for generating virtual outcrops (VO) and high-resolution digital terrain models (DTMs). In comparison with more sophisticated and expensive techniques such as airborne LiDAR scanning or terrestrial laser scanning, SfM-MVS is a fast low-cost method which with careful use of ground control points, can produce models which are comparable to other digital survey methods for spatial accuracy. In this study, the effectiveness of SfM-MVS in a series of quantitative case studies in sedimentary and basin analyses is discussed. Focus is placed on how the research questions define the workflow strategy to know the limitations, sources of error and potential utility that the SFM-MVS technique has when a virtual sedimentary system is interpreted. Three case studies of different sedimentary environments, previously analyzed with traditional fieldwork techniques, were selected and re-analyzed. For each case study the objective was to resolve quantitative questions that were not possible to determine without the use of VO or DTMs. Questions include: (i) geometrical restoration of a growth strata succession associated with thrust systems; (ii) stacking patterns of littoral ridges during a relative sea-level fall after the Holocene climatic optimum; and (iii) quantification of lake level fall during the past 44 years of a closed lake basin. The results of the work show that the technique has significant application in the analysis of sedimentary systems. However, since geological interpretations depend on the quality of the models that are generated, planning and construction of the VO or DEMs along with their validation are essential to ensure reliable results.
\end{abstract}

\section{Introduction}

Sedimentary forms, stacked strata, and landscapes are inherently three-dimensional (3D) in nature, which have classically been treated in 2D for analysis. Important spatial distortion exists when we simplify 3D objects in a 2D representation (e.g., Marjoribanks, 2010; Pavlis and
Mason, 2017), especially in the studies focused on the distribution, geometry and quantification of geological bodies and the analysis of sedimentary forms, as well as of the tectonic structures (Hodgetts et al., 2004; Wilson et al., 2005). Before the '90s, geoscientists had few ways to display, analyze and interpret the full dimensionality of their 3D data, other than combining 2D geological maps, cross-sections, and

\footnotetext{
* Corresponding author.

E-mail address: abilmes@cenpat-conicet.gob.ar (A. Bilmes).
} 
orthographic and stereographic projections. During the last decade of the twentieth century significant advances in 3D geosciences visualization and modelling techniques in addition to new field data acquisition methods (e.g., airborne LiDAR scanning, Terrestrial laser scanning, 3D Seismic Surveys, multi-beam sonar), paved the way to a technological revolution in the field of geomatics, in particular with the development of virtual outcrops and high-resolution digital terrain models (DTMs) (Bellian et al., 2005; McCaffrey et al., 2005; Jones et al., 2009; Enge et al., 2010; Fabuel-Perez et al., 2010). Although virtual outcrops and DTMs demonstrated excellent performance in geological fieldbased investigations, the large economic investment required to collect and process them have limited their use mainly to oil and mining industry and prototype scientific research programs (e.g., Brodaric, 1997; Brimhall et al., 2002; Clegg et al., 2006; Pringle et al., 2006; Enge et al., 2007; Buckley et al., 2008; Hodgetts, 2009; Howell et al., 2014; Rarity et al., 2014). In recent years a new technique to obtain virtual outcrops or DTMs using a new photogrammetric approach called "Structure from Motion-Multi-View Stereo (SfM-MVS)" (Furukawa and Ponce, 2007; Hirschmüller, 2008; Harwin and Lucieer, 2012; Westoby et al., 2012; Ružić et al., 2014; Tonkin et al., 2014) has emerged. This method allows constructing 3D models similar to those obtained with laser scanning from photographs alone. This has greatly enhanced the applicability of VO technique with the additional advantage of being lowcost. Developed in the 1990s as an algorithm for the computer vision community, the SfM-MVS technique is a photogrammetric method that produces 3D point clouds and mesh models using multiple overlapping offset images (Spetsakis and Aloimonos, 1991; Boufama et al., 1994; Szeliski and Kang, 1994). In comparison with traditional photogrammetry, the great advance of this method is that the geometry of the scene, camera positions and orientation are solved automatically without the need to specify a priori, a network of targets with already known 3D positions (James and Robson, 2012; Carrivick et al., 2016). A typical complete workflow to develop this technique involves: (1) fieldwork component to establish ground control points and acquire the photoset, using hand-held photogrammetry, poles or unmanned aerial vehicles (UAV; Fig. 1); (2) computer processing and reconstruction of the 3D scene (i.e. "Structure from Motion-Multi-View Stereoworkflow s.s."); and a (3) post-processing stage to scale and geo-reference the model (Fig. 2; for a detailed review see Snavely et al., 2006, 2008). The SfM-MVS technique has been applied in diverse physical geology studies that involved 3D analysis and interpretation of virtual outcrops and/or DTMs, and is starting to be also used in sedimentary and tectono-stratigraphic analysis (e.g., Chesley et al., 2017; Nieminski and Graham, 2017; Nesbit et al., 2018). In this context, this contribution illustrates the effectiveness of the Structure from Motion-Multi-View Stereo photogrammetry technique in the resolution of quantitative case studies for different sedimentary environments. The focus of this study is on defining the most appropriated workflow strategy to solve diverse research questions while further identifying the limitations, source of error and potential utility of the SfM-MVS technique interpreting a virtual outcrop model. Three case studies previously analyzed with traditional fieldwork techniques were selected and re-analyzed (Fig. 2). For each case study the objective was to answer questions that could not be resolved without the use of virtual outcrops and DTMs, such as: (i) restoration of sedimentary growth strata associated with thrust systems in one of the Neogene Andean Foreland Basins of northernmost Patagonia; (ii) accretional and progradational stacking patterns of Atlantic littoral ridges during a relative sea-level fall after the Holocene climatic optimum; and (iii) quantification of lake level fall during the past 44 years of a closed lake basin located in Central Patagonia. Potential and limitations of this low cost and easy-to-use technique are discussing considering the results obtained in these contrasting sedimentary environments. To improve geological interpretations and construct more reliable VO or DEMs using the SfM-MVS approach this study also pondered the early planning of the survey, the photo acquisition approach and the quality assessment of the 3D model.

\section{Workflow}

To acquire VO and DTMs using the SfM-MVS technique implemented in the analysis of the three case studies a number of separate image sets were obtained using two different platforms: hand-held photogrammetry-Terrestrial SfM (TSfM) - and unnamed aerial vehicles (UAV) - Aerial SfM (ASfM) — (Fig. 1). A summary of the main
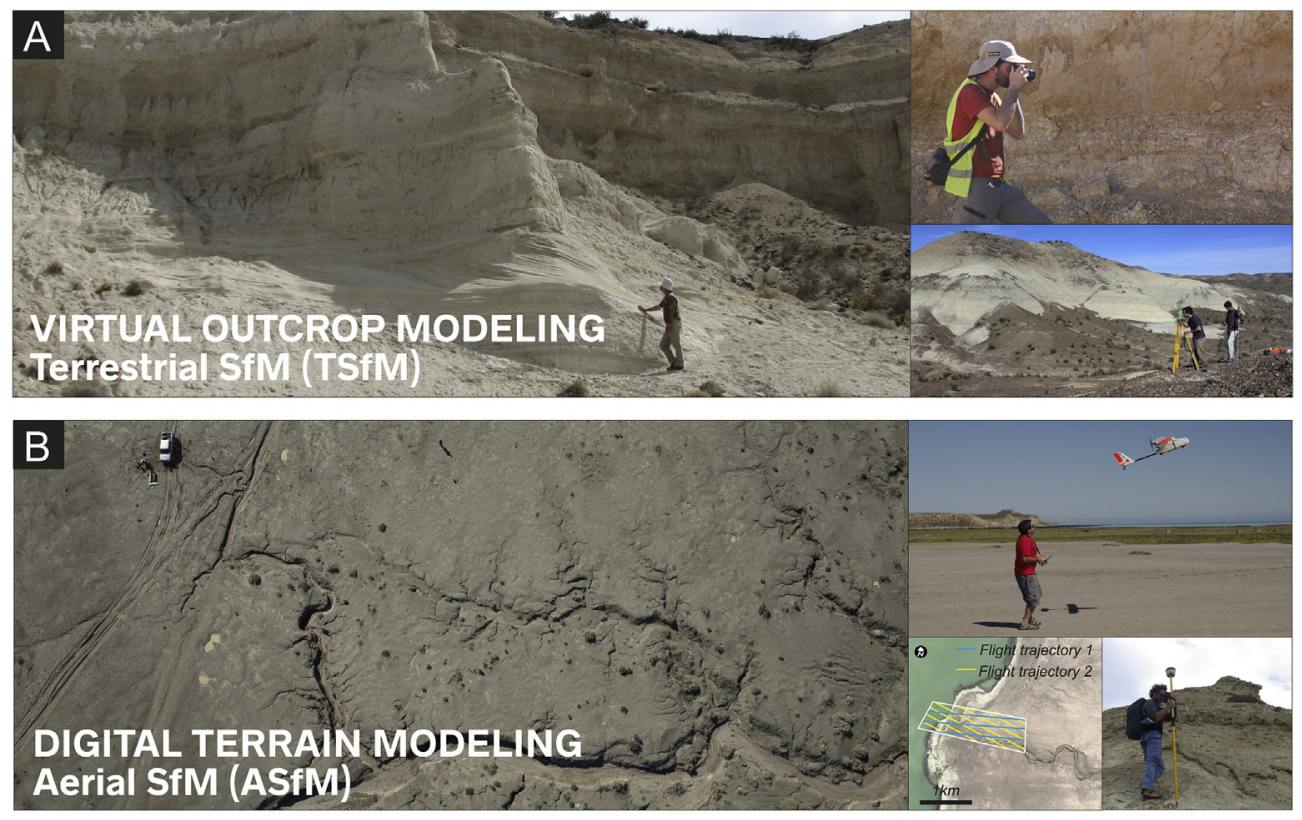

Fig. 1. Field data acquisition. A. Terrestrial SfM: Digital outcrop modelling using hand held photos and a Total Station. B. Aerial SfM: Digital terrain modelling using aerial UAV photogrammetry and a differential GPS. 


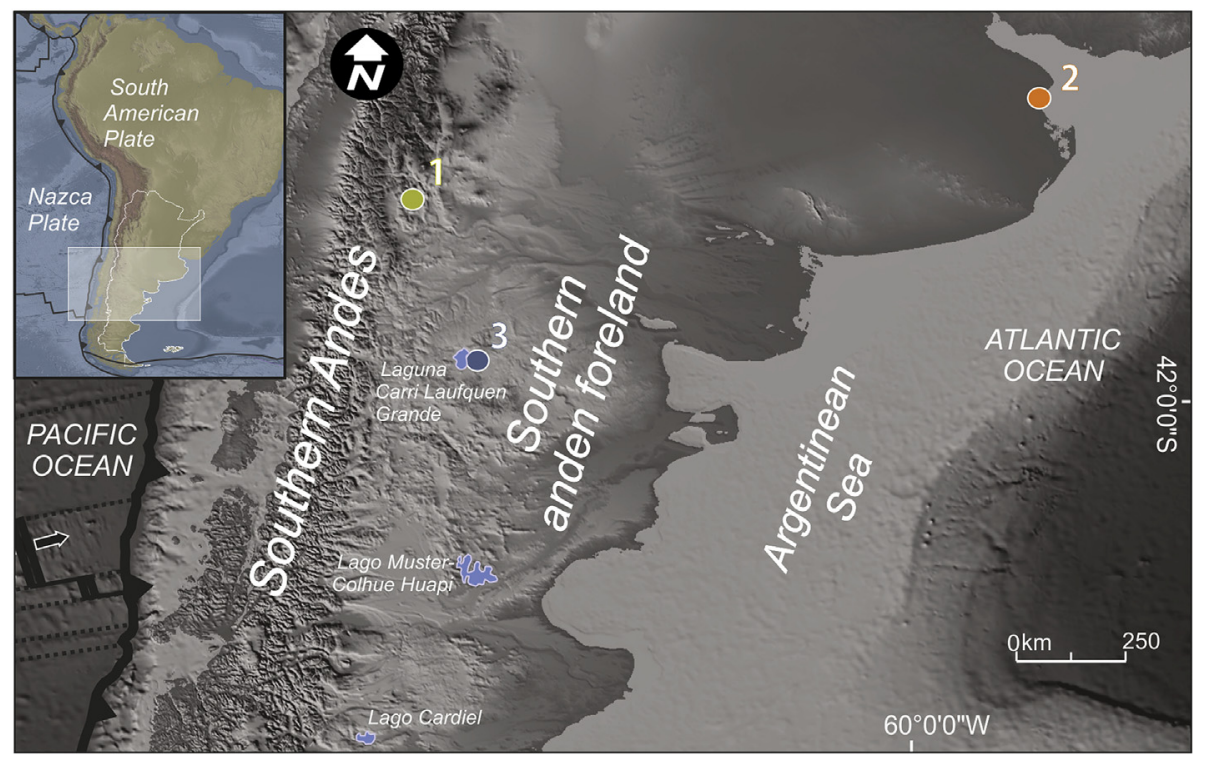

Fig. 2. Location of the study areas in the southern Andean Foreland and Atlantic littoral zone, Argentina. 1. Growth strata of the Catán Lil Basin. 2. Beach ridges of Bahía Samborombón. 3. Lake shorelines of Laguna Carri Laufquen Grande.

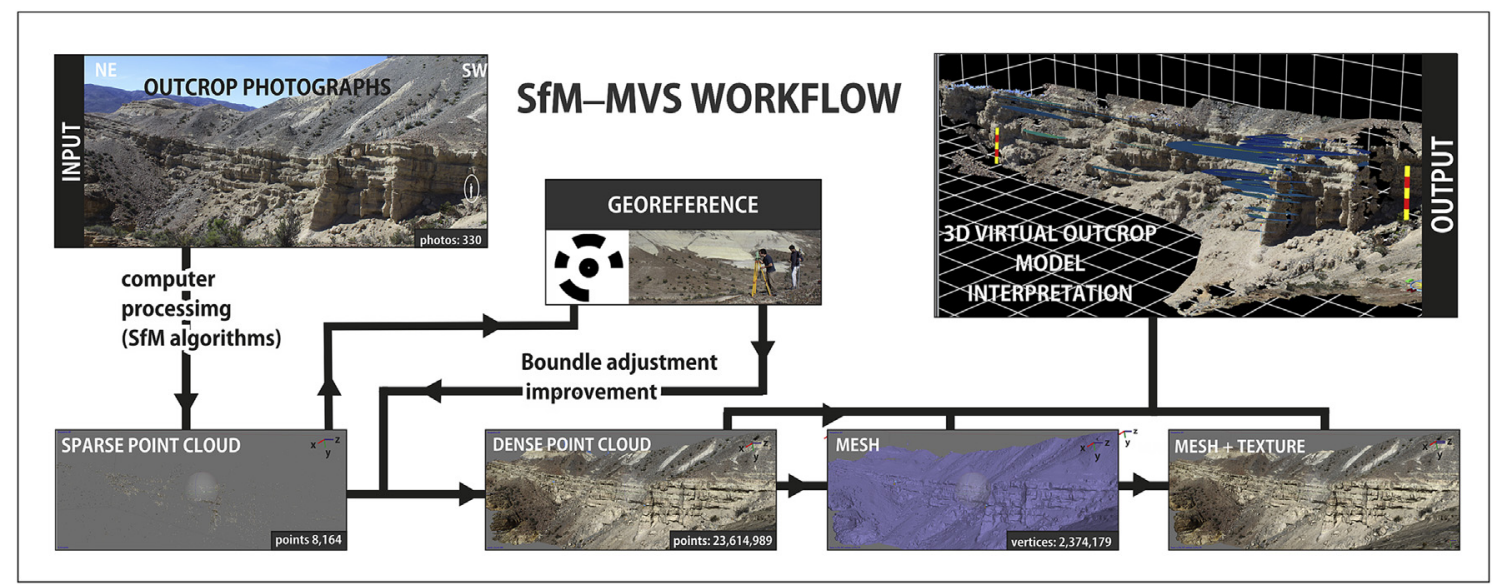

Fig. 3. SfM-MVS workflow. Scale bar in the 3D virtual outcrop model is $5 \mathrm{~m}$.

methods and workflows used in the analysis is provided (Fig. 3); however a detailed description of the SfM-MVS process is beyond the scope of this paper. Readers interested in specific characteristics of the SFM-MVS process can consult detailed contributions (Snavely et al., 2006; Snavely et al., 2008; James and Robson, 2012; Westoby et al., 2012; Fonstad et al., 2013; Javernick et al., 2014).

\subsection{Field data acquisition}

The first step in the workflow is the acquisition of photographs (Fig. 1). A major advantage of this technique versus traditional photogrammetry is the possibility to generate the models with little to no camera calibrations or spatial orientation (Carrivick et al., 2016). In case studies 1 and 2, due to the high relief topography, small area and shape of the outcrop, a Terrestrial SfM (TSfM) approach was chosen to construct the virtual outcrops (Fig. 1A, Table 1). The datasets comprised 405 images from 222 camera positions for case 1 and 161 images from 156 positions in case 2 . Photographs were taken with the camera's optical axis perpendicular and oblique to the outcrop surface to avoid distortion in the model (James and Robson, 2014). Photo acquisition was performed with different range distances which covered the whole outcrop-scale $(100-500 \mathrm{~m})$ to the mesoscale $(10 \mathrm{~m})$. Given the improved accuracy of SfM reconstructions with larger overlapping image pairs, camera positions were carefully chosen during fieldwork to maximize photo coverage, convergent imagery and synoptic viewpoints of the studied outcrops (Fig. 4). It is important to stress that after photo acquisition, a low-resolution image matching alignment between all photos was performed in order check coverage and convergence. This determined the pre-processing validation of the models and improved the acquisition strategy. For case 1 photographs were taken orthogonal to the outcrops with a Canon SX40 HS (focal length $42 \mathrm{~mm}$; $16 \mathrm{Mpx}$ ), while in case 2 a Lumix DMC-GX7 Mirrorless Micro Four Thirds (focal length $18 \mathrm{~mm}$; $10 \mathrm{Mpx}$ ) was used. In case 3, where the objective was to generate a high-resolution digital terrain model of several square kilometers in areal extent while keeping a resolution of only centimeters, an aerial SfM platform (ASFM) was chosen. Photographs were collected using an autonomous fixed-wing UAV (MAJA-Bormatec; Fig. 1B). In this case, a Ricoh GR camera (focal length $18.3 \mathrm{~mm}$, which is equivalent to $28 \mathrm{~mm}$ on a $35-\mathrm{mm}$ camera; $16 \mathrm{Mpx}$ ) was suspended below the UAV with a nadir viewing angle. The camera was set up to take a picture every $1 \mathrm{~s}$ (interval timer, auto shooting). The itinerary of the flight was set and controlled with software Mission Planner 1.3.39 (Fig. 1B). The flight height was $\sim 140 \mathrm{~m}$ with an average velocity of $12 \mathrm{~m} / \mathrm{s}$. Flight paths were previously designed to ensure more than $70 \%$ overlap and more than $60 \%$ side lap among photographs. The flight trajectory consisted of three parallel flight lines covering the entire area 
Table 1

Workflow and specifications for each 3D model.

\begin{tabular}{llll}
\hline Geological model & Case study 1 & Case study 2 & Case study 3 \\
\hline $\begin{array}{l}\text { Model to achieve } \\
\text { Covered surface }\end{array}$ & VO & & DTM \\
Platform & $0.313 \mathrm{Km}^{2}$ & $0.001 \mathrm{Km}^{2}$ & $\begin{array}{l}1.3 \mathrm{Km}^{2} \\
\text { Fixed wing }\end{array}$ \\
& Hand-held & & UAV \\
Camera & Lumix DMC- & Canon SX40 & Ricoh GR \\
& GX7 & HS & \\
Mpx & 16 & 10 & 16 \\
Focal length & $40 \mathrm{~mm}$ & $18 \mathrm{~mm}$ & $18.3 \mathrm{~mm}$ \\
Photos & 405 & 161 & 1878 \\
Camara stations & 222 & 156 & - \\
Range from camera to outcrop & $15-800 \mathrm{~m}$ & $10-350 \mathrm{~m}$ & $140-165 \mathrm{~m}$ \\
$\begin{array}{l}\text { Processing software } \\
\text { Tie points x10 }\end{array}$ & Agisoft Photoscan professional & \\
Dense cloud x10 & 60.8 & 52.4 & 514.8 \\
Mesh faces x10 & 59.54 & 11.58 & 119.31 \\
Georreferenciation: field & - & - & 7.85 \\
$\quad$ Total Station & & dGPS \\
Georreferenciation: & 7 & 6 & 6 \\
$\quad$ Control points & & & \\
Final model resolution (m) & 0.02 & 0.02 & 0.04 \\
Model RMSE in m (using & 0.30 & 0.11 & 0.02 \\
$\quad$ control points) & & & ArcGIS 10.1 \\
Post-processing software & Cloud compare - VRGS & \\
\hline
\end{tabular}

(Flight trajectory 1 in Figs. 1B and 4c). Additionally, to avoid the doming effect described in James and Robson (2014), a sequence of four lines oblique to the former was performed in a second flight (Flight trajectory 2 in Figs. 1B and 4c). For the three cases vegetation is sparse or absent, minimizing issues such as occlusion effects and enhancement of residual errors (Micheletti et al., 2015; James et al., 2017).

Control points with centimeter precision of X, Y, Z coordinates were obtained to set a scale and georeference the 3D models. Several markers used as ground or checkpoints were measured in the field (Table 1) and spatial coordinates of these points were obtained, in cases 1 and 2 with a Stonex ${ }^{\circledR}$ Total Station (TS; Fig. 1A, inset) and in case 3 with a Trimble $^{\circledast}$ R2 differential GPS (dGPS; Fig. 1B, inset). For cases 1 and 2, the Total Station was positioned and oriented with 2 coordinates obtained with a GPS Garmin 30. These points were separated by approximately $2 \mathrm{~km}$ from each other. All ground control points (GCP) and checkpoints (CCP) coordinates were measured from a single station. Each point was measured with a prism with an accuracy of \pm 2 $\mathrm{mm}+2 \mathrm{ppm}$.

\subsection{Data processing and post-processing}

The workflow to generate the 3D dense cloud is quite similar for both free open source and commercially available software (e.g., Visual SfM, Boundler, AgiSoft PhotoScan). A feature detection function allows the generation of a sparse point cloud and uses this to solve the camera's intrinsic and extrinsic orientation parameters and the relative position (Fig. 2).

The high density of overlapping images ( $>9$ photos) used in the field (section 2.1) allowed us to automatically estimate each point location of the sparse cloud (Fig. 4). The latter is important because previous work had demonstrated that a high density of overlapping images improves virtual outcrop accuracy (James and Robson, 2012; Cawood et al., 2017). From the sparse cloud, a dense point cloud was generated using several algorithms (e.g. Multi-View; Seitz et al., 2006). A triangulated mesh can be created from the sparse or dense point cloud; in these cases the dense clouds were used. Once the triangulated surface was generated, it was draped with images from the photos (Fig. 2). The models were georeferenced with ground control points and the accuracy of the model was determined with the root-mean-square error (RMSE; Table 1). Based on this methodology a positive correlation between the accuracy of the models and the range of the photos is expected (i.e. below $0.2 \mathrm{~m}$ for ranges of $200 \mathrm{~m}$; Carrivick et al., 2016). A full discussion of the inaccuracies and validation methods is also provided in section 5 .

In this work, the three models were processed with AgiSoft PhotoScan ${ }^{\circledast}$ professional to perform the whole workflow. For cases 1 and 2 the georeferenced points of the dense cloud were exported to a point cloud viewer (i.e., CloudCompare ${ }^{\circledR}$ V2.6.1) to perform a subsample of points in order to import it to specific software for 3D digital outcrop analysis. Visualization and interpretations were performed in the Virtual Reality Geological Studio (VRGS) software ${ }^{\circledR}$. VRGS was used to map and measure geological features in 3D, including bed thickness and orientations of geological planes. In this work, the points of the dense cloud were preferred as it represents raw data and not an interpolation, eliminating problems like pixel smear and other distortions from image draped texture (Pavlis and Mason, 2017). Dip and dip direction of several beds were also obtained. These data were exported and plotted with Stereonet software ${ }^{\circledast}$. For case 3, the georeferenced triangulated mesh was exported as a DEM file from AgiSoft PhotoScan. In this case, visualization and interpretation of the DEM were performed using ArcGis10.1 ${ }^{\oplus}$.

In order to assess the potential sources of error and inaccuracies introduced during data acquisition, validations of the models using field control data were performed (Fig. 5). For Case 1, dip and dip azimuth measurements collected in the field using traditional compass-clinometer were compared with dip and dip azimuth measurements from the VO (Fig. 5B). A comparison was performed on two key surfaces of the VO using the Fisher mean vector and dispersion of poles thorough $\mathrm{k}$ constant (Fisher et al., 1987). For Case 2, validation of the model was performed using 20 Total Station (TS) checkpoints in order to measure dip and dip azimuth for the bottomset, foreset and topset clinoforms (Fig. 5A; Supplementary data). The RMSE of the model using TS Check Points was used to estimate the error of dip and dip azimuth measurements in the VO using the 3-Point Problem approach (Martinez-Torres et al., 2012). In case 3 the $\mathrm{z}$ position of the DEM constructed with the ASfM (Grid size $30 \times 30 \mathrm{~cm}$ ) was compared with elevations measured at 271 Check Points (dGPS Control Points not used to georeference the model). Point-to-raster comparison was performed ArcGis10.1 ${ }^{\circledR}$ (Fig. 5C; Supplementary data).

\section{Applications of structure-from-motion to diverse sedimentological problems}

Three case-studies previously analyzed with traditional field techniques have been re-analyzed using virtual outcrops and DTMs constructed with this novel technique (Fig. 3). These three case-studies are located between the southern Andean Foreland and the Atlantic littoral zone in Argentina. The following section provides a summary of the geological setting followed by the main issue to address, the dataset and the new results obtained using VO and DTMs constructed with the SfMMVS approach.

\subsection{Case study 1 (C1): growth strata analysis of an intermontane piggy- back basin}

Growth strata (Suppe et al., 1992) are syn-tectonic beds deposited during the evolution of faults and folds. They occur in contractional and extensional tectonic regimes (e.g., Gawthorpe and Hardy, 2002; Vergés et al., 2002), and their geometry responds to the rates of accommodation space created by the deformation and the supply of sediment (Poblet, 2012 and reference therein). Their study allows us analyze the interplay between tectonics and sedimentation which may be difficult to decouple, especially since many examples are typically overprinted by later deformation.

Along the North Patagonian Andes, the orogenic uplift and development of a fold and thrust belt during the Neogene formed a foreland retroarc system (Bilmes et al., 2013, Figs. 5 and 6A). The nature of the 


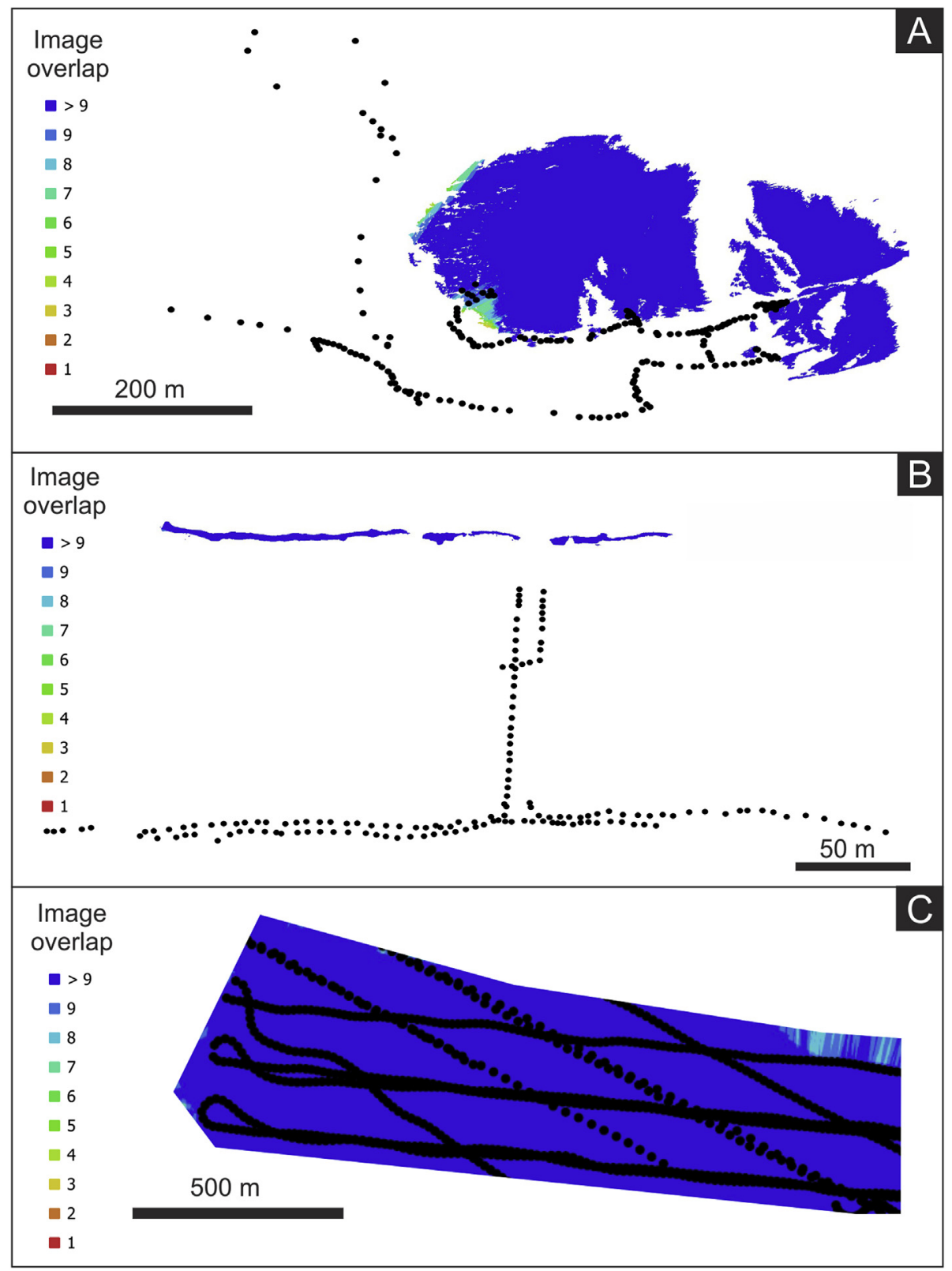

Fig. 4. Camera location (black dots) and image overlap of 3D models. A. Virtual Outcrop reconstruction of Case 1 using TSfM. B. Virtual Outcrop reconstruction of Case 2 using TSfM. C. High-resolution terrain model reconstruction of Case 3 using ASfM.

infill of the foreland retroarc system was dominated by a close interaction between sedimentation and volcanism that took place during the orogenic phase. The Catán Lil Basin is one of the best-exposed Neogene basins located at the wedge top of this foreland retroarc system (GarcíaMorabito et al., 2011; García Morabito and Ramos, 2012, Fig. 6A). The Catán Lil Basin is $15 \mathrm{~km}$ long and $10 \mathrm{~km}$ wide syncline associated with Andean, west-verging thick-skinned fold-and-thrusting (D'Elia et al., 2008; García Morabito and Ramos, 2012; Franzese et al., 2018 Fig. 6A and B). The infill of the Catán Lil Basin is $\sim 300 \mathrm{~m}$ thick and started after a major hiatus of almost 100 m.y. It comprises volcaniclastic alluvialfluvial deposits and basaltic lava flow deposits (D'Elia et al., 2008; Franzese et al., 2018). The eastern margin of the basin is a west-verging, $\mathrm{N}$-trending, S-plunging, forced-fold anticline that was the active basin-boundary range during the basin configuration (García Morabito and Ramos, 2012, Fig. 6A and B). The forelimb is composed of vertical to overturned Mesozoic strata (pre-growth strata; Fig. 6B), on top of which the Neogene fill onlaps the growth strata with a progressive unconformity (sensu Suppe et al., 1992; Allmendinger et al., 1997,
Fig. 6C). Previous works describe three clastic sequences in the basin, the first two under syn-kinematic tectonic conditions and a younger post-kinematic (D'Elia et al., 2008; Franzese et al., 2018, Fig. 7B). Sequence 1 (S1) is composed of up to $243 \mathrm{~m}$ thick volcaniclastic apron deposits, whereas the overlying Sequence 2 (S2) encompasses up to $59 \mathrm{~m}$ of epiclastic sandstones and conglomerates interbedded with siltstones that are interpreted as alluvial-fluvial deposits. The complex growth of this succession with the progressive development of discordances, combined with erosion of the crest of the anticline and discontinuous outcrop exposures, makes a high-resolution analysis using conventional field methods challenging. While previous investigations have determined the general trend of the progressive discordances within the infill megasequence (García-Morabito et al., 2011; García Morabito and Ramos, 2012; Franzese et al., 2018), no geometrical analysis has been done to establish strata terminations and relationships related to the timing of the growing structure. Therefore this dataset is highly suited to analysis using virtual outcrops, especially when combined with new sedimentary sections (1:100). 


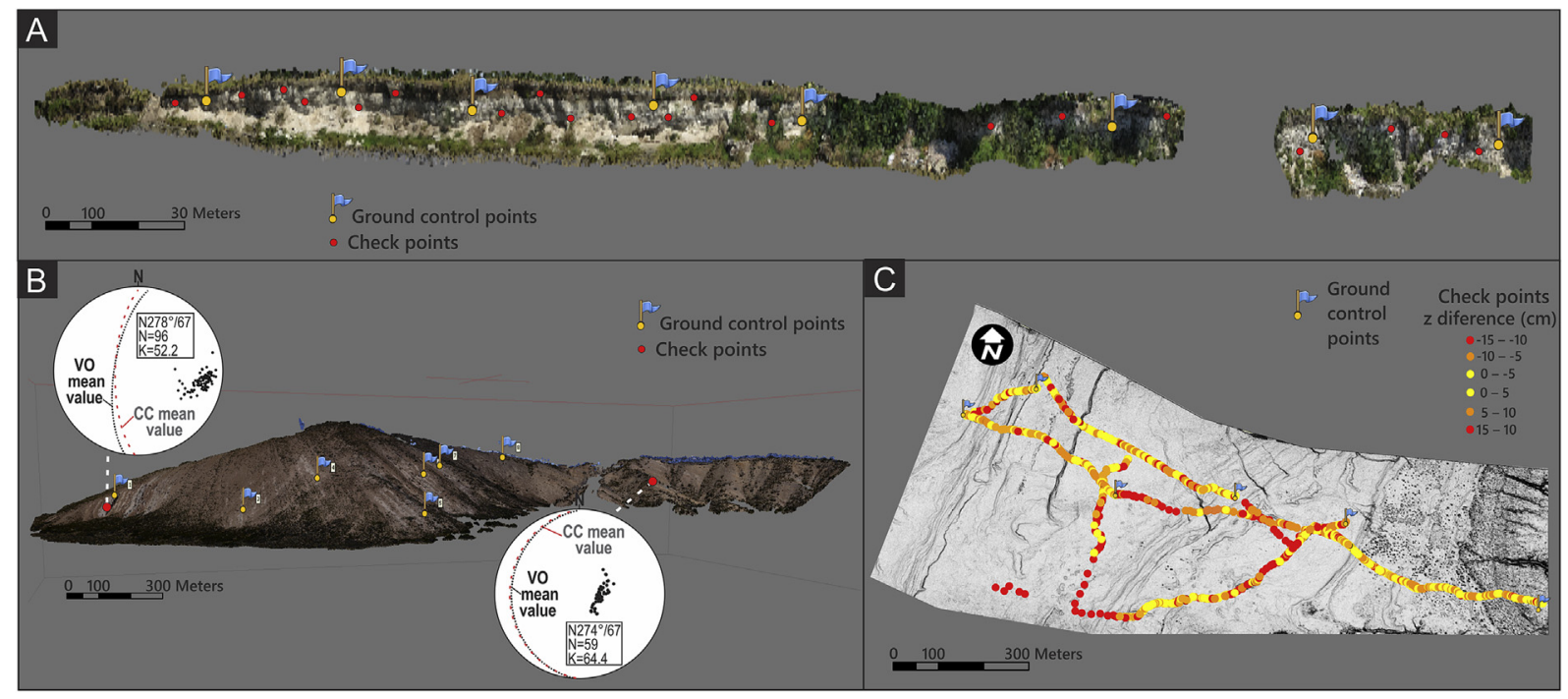

Fig. 5. Quality Assessment of Virtual Outcrop (VO) and high-resolution digital terrain model (DEMs) reconstructions using field data. A. Case 2, Validation of the VO using Total Station check points (n 20). B. Case 2, Validations of the VO by comparing dip and dip azimuth measurements collected in the field using traditional compass-clinometer (CC) versus dip and dip azimuth measurements of the VO. Comparison was performed using the Fisher mean vector and dispersion of poles thorough $\mathrm{k}$ constant (Fisher et al., 1987). C. Case 3, Validations of the DEM by comparing the z position of the DEM constructed with the ASfM with z positions of 271 Check Points (dGPS Control Points not used to georeference the model). For detail error values of each case study see Supplementary material.

\subsubsection{Dataset and results}

Growth strata were systematically measured from the VO (Fig. 6D). Measurements of the dip and dip direction of bedding and bounding surfaces were analyzed in order to quantify tilting during different pulses of deformation and to determine sets of unconformity bounded strata with their corresponding rotation axis. In order to test the confidence factor of the measurements taken from the VO, control surfaces were chosen to compare with the corresponding compass-clinometer field-measurements (cf., Franzese et al., 2018, Fig. 5B). Two control surfaces were selected, one near the base and the other one near the top of the sequence 1 , to calculate the mean principal orientations of bedding planes and vector dispersion of poles to bedding (i.e., k constant; Fisher et al., 1987). Results obtained using the VRGS three-point method determine a $k_{1}=55.2(\mathrm{~N}=96)$ and $\mathrm{k}_{2}=64(\mathrm{~N}=59)$ for surfaces 1 and 2, respectively (Fig. 5B). The comparison of these results with compass clinometer values determined a major error of up to $11^{\circ}$ for the dip-azimuth and up to $2^{\circ}$ for the dip values (Fig. 5B). The values obtained indicate low dispersion and are similar to those obtained in other validation analysis of VO constructed with ASfM or LIDAR (Cawood et al., 2017; see discussion). The analysis of each bedding surface along the VO (Fig. 7B) was performed using the VRGS threepoint method, with a distance between points of $5 \mathrm{~m}$, taking $\mathrm{N}>10$ (and up to 30) to obtain a unique weighted value with the Stereonet software $^{\circledast}$. For the analysis of the growth strata pattern, interstratal surfaces were mapped as polylines. The polylines were transformed in planes and were extended to obtain the geometrical relationships between strata (Fig. 7A). This projection was made in a plane perpendicular to the mid-rotation axis of the growth strata.

Our results show that in the forelimb of the Catán Lil Basin (Fig. 6B and $\mathrm{C}$ ), the Neogene strata are characterized by a progressive decrease in bedding dip from $\sim 80^{\circ}$ overturned strata at the base to $6^{\circ}$ at the top of the succession (Fig. 7). The geometrical analysis of the progressive discordances together with the strata dip variations across the sedimentary section define five different dip domains (D1, D2, D3, D4 and D5; Fig. 7A). These domains are characterized by changes in the progressive discordance relationships (i.e., rotative offlap or rotative onlap patterns; Anadón et al., 1986), and in the ratio between the cumulative thickness of strata and cumulative angle of rotation (Fig. 7A and B). The D1 is developed as a rotative offlap whereas the "bed by bed" measurement from the base to the top, allows to determine a tilting average between the progressive discordances of $1.08^{\circ} / \mathrm{m}$ (Fig. 7A). The D2 presents an average difference between the progressive discordances of $0.13^{\circ} / \mathrm{m}$. The D3 is developed as a rotative offlap with an average difference between the progressive discordances of $0.39^{\circ} / \mathrm{m}$. The D4 is developed as a rotative onlap presenting an average difference between the progressive discordances of $0.05^{\circ} / \mathrm{m}$. Finally, the D5 is developed as a rotative offlap with an average difference between the progressive discordances of $0.25^{\circ} / \mathrm{m}$. To this scale, the observed domains may be discriminated with changes in the slope of the curve aligned that matches with the dataset (Fig. 7B). The first four domains are developed completely in the volcanic apron deposits of the S1, whereas the last domain includes the top of the S1 and all the alluvial-fluvial deposits of the S2.

The analysis of the VO allowed bed by bed measurements of this syn-orogenic sequence, dominated by volcaniclastic materials exposed in a badland landscape. The 3D analysis carried out allowed: (i) the recognition and measuring of strata surfaces that define tilting pulses; (ii) the geometrical reconstruction of eroded progressive discordances in order to establish their stratal termination; and (iii) the establishment of domains that characterized cyclic rotation pattern. Cycles consist of domains of rotative offlap and major accumulative tilting per meter followed by domains of rotative onlap/aggradational stacking pattern with progressively lower accumulative tilting per meter until attaining the post-tectonic stage of the system (Fig. 7B). In the present case study, the relationships established between the diverse domains are interpreted as the recording of three tectonic events that decelerated during the evolution of each deformational event (D1 to D2, D3 to D4, D5 to post-tectonic). From the onset of the syn-orogenic phase to the post-tectonic phase, each one of the cycles recorded have a lower degree of rotation towards the top (i.e., $1.08^{\circ} / \mathrm{m}, 0.39^{\circ} / \mathrm{m}$ and $0.25^{\circ} / \mathrm{m}$, respectively) and does not necessarily matches with a change in the sedimentary system (Fig. 7B). This pattern is comparable with "composite progressive unconformity" described by Riba (1976) to refer the offlap-onlap pair related to the acceleration-deceleration deformational events. The pattern recorded is consistent with the progressive deceleration occurred during the growth of forced-fold anticlines validated in natural case-studies or numerical models (e.g., Suppe et al., 1992; Allmendinger et al., 1997; Storti and Poblet, 1997; Shaw et al., 2004). 

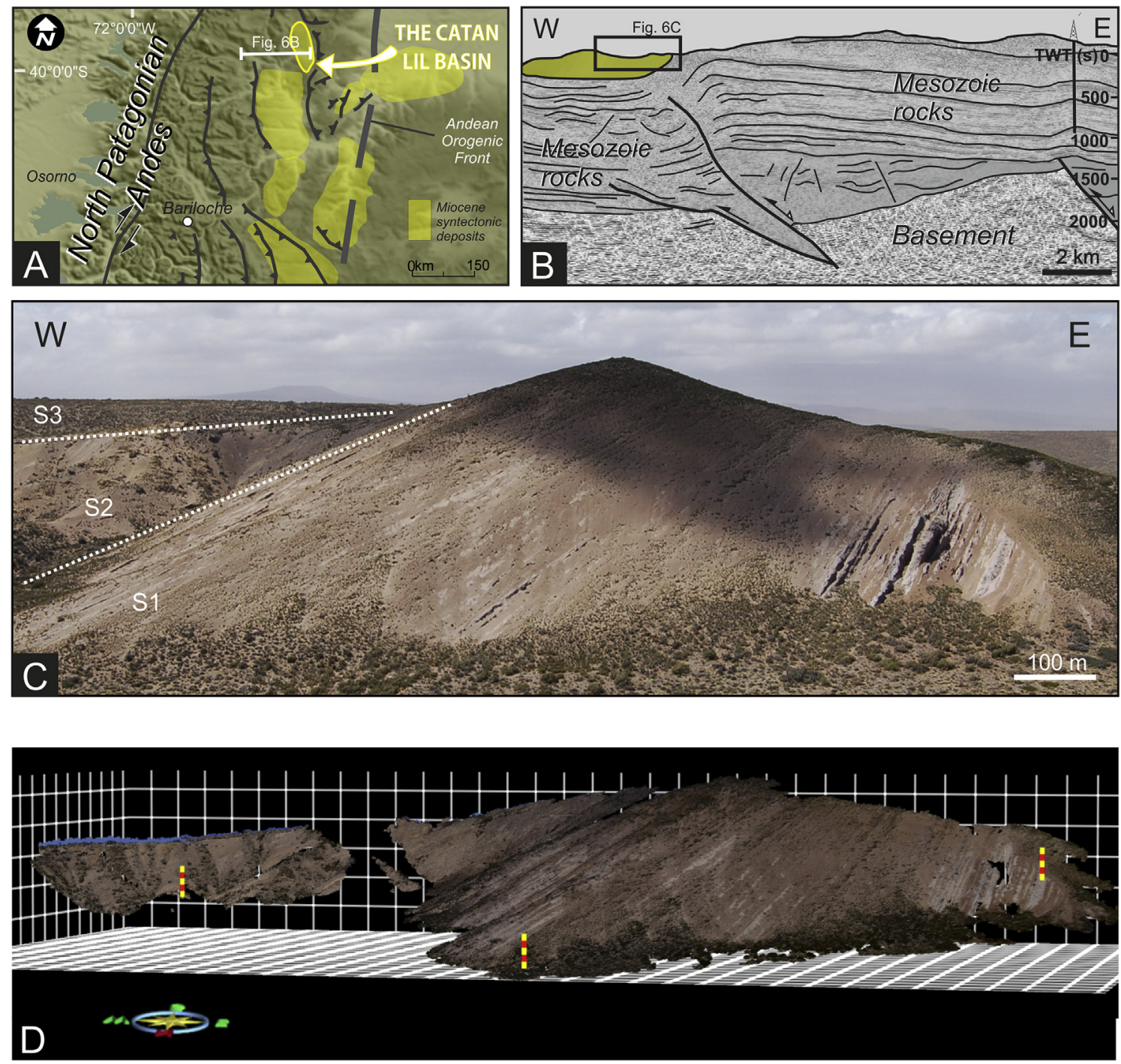

Fig. 6. Case Study 1- Growth strata in the Catán Lil Basin. A. Geological setting. B. Geological cross-section of the Catán Lil Basin (modified from García Morabito et al., 2011). C. Outcrop panorama of grow strata analyzed in this study. S1, S2 and S3 represents sequences described in Franzese et al., (2018). 3D virtual outcrop model interpretation. (Scale bar $5 \mathrm{~m}$ ).

\subsection{Case study 2 (C2): clinoforms in Holocene marine beach ridges}

Beach ridges are landforms that develop on some wave-influenced progradational coasts (Tamura, 2012). Beach ridge formation involves accretion of material on the beach-face by wave, tidal and aeolian processes. Beach ridges can record sea-level changes and shoreline progradation (e.g., Otvos, 2000; Tamura, 2012; Weill et al., 2012; Zecchin and Catuneanu, 2013). The Argentinean littoral zone includes good quality examples which were mainly since the Last-Glacial Maximum (LGM; e.g., Codignotto and Aguirre, 1993; Violante et al., 2001; Richiano et al., 2012, Fig. 3). Spectacular examples of Holocene ridges are preserved at Bahía Samborombón on the coast of Buenos Aires province in Argentina (Fig. 8). The development of these beach ridges is consequence of the final sea level maximum $(+5$ macsl) reached between 7 and 5 ka BP (Violante and Parker, 2004). Beach ridges crop out up to $5 \mathrm{~km}$ inland showing a parallel orientation to the present coastline (Fig. 8A). The geomorphology and stratigraphy of these deposits have been studied for more than 60 years (since Frenguelli, 1950) but their sedimentological evolution has only been investigated in detail more recently (Spalletti et al., 1987; Codignotto and Aguirre, 1993; Violante et al., 2001; Richiano et al., 2012). The Bahía Samborombón littoral drift of the shell ridges during the mid-Holocene (ca. 7-5 ka.) is still controversial. Some authors consider that the main direction of the littoral drift was towards the north based on general geomorphological data and the geochronology of the studied deposits (Codignotto and Aguirre, 1993; Spalletti et al., 1987). Conversely, other authors proposed a littoral drift towards the south from the headlands to the interior of the bay (Violante et al., 2001). A detailed sedimentological study carried out by Richiano et al. (2012) addressed the main controlling factors that govern shell ridge formation without providing a final answer to the issue of the littoral drift direction. Previous methods used for field observations (e.g., 2D architectural panel interpretation or combination of $2 \mathrm{D}$ cross-sections) did not reveal paleocurrent information or solve littoral drift direction, primarily because it is difficult to measure low angles smooth slopes over large distances ( $>100 \mathrm{~m}$ ) and the majority of outcrop cuts are highly oblique to the ridges making it difficult to accurately parameterize the different sedimentary units.

The central part of the Bahia Samborombón was selected for the current study. The study location includes an artificial channel which produces high-quality exposures of the beach ridges (Fig. 8A-C). In this area different ridges are amalgamated and several hierarchies of surfaces were determined in the field (Fig. 8C). The main geomorphological surfaces (1-9 in Fig. 8C) define the limits of each ridge body 

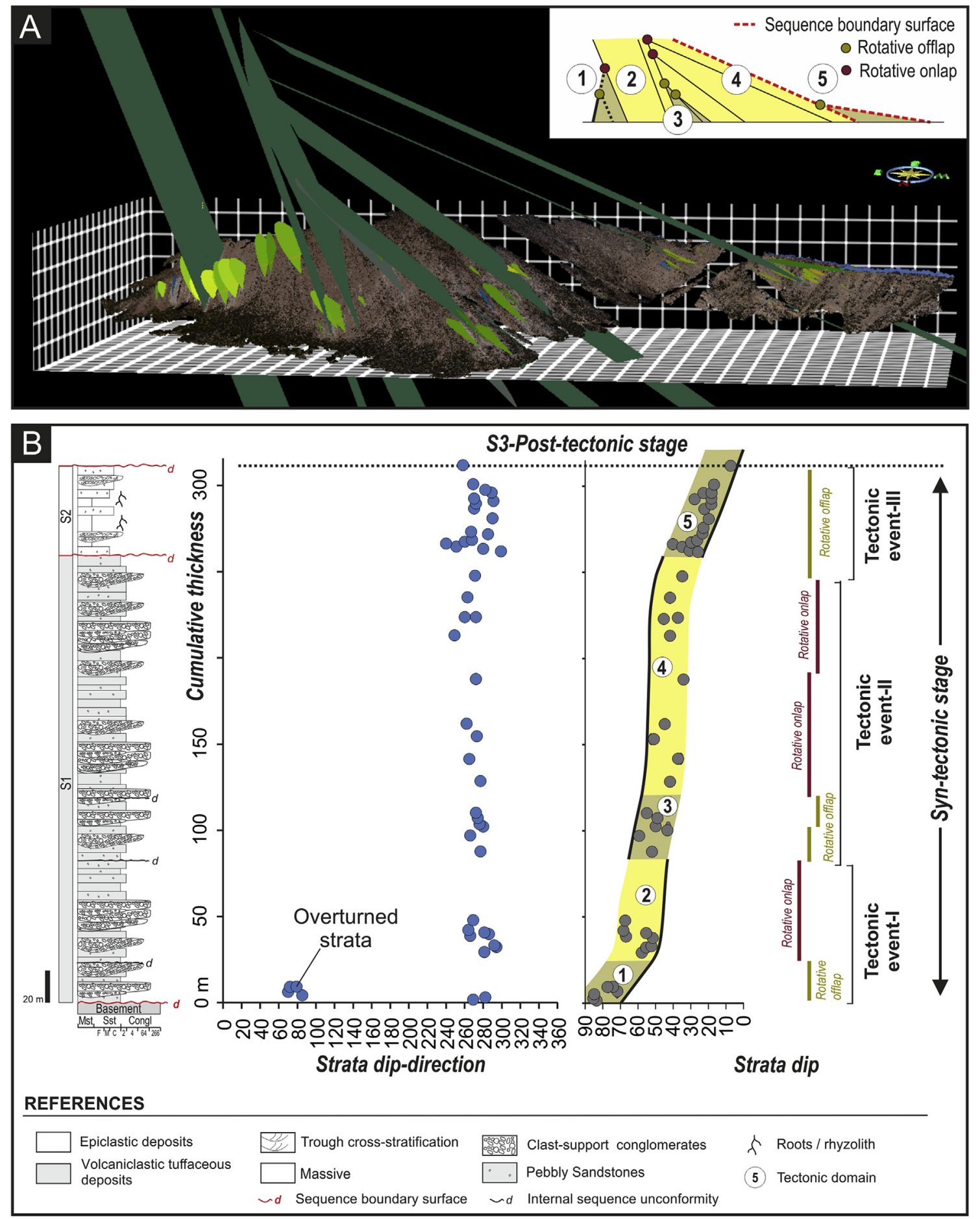

Fig. 7. A. Geometric analysis of the progressive discordances allowed determining five different domains, characterized by changes in the progressive discordance relationships, such as rotative offlap or rotative onlap patterns. B. Sedimentary section of the basin infill, cumulative thickness versus strata dip-direction and strata dip mean values calculated with Stereonet $\subset$.

representing major events in the littoral environments. The first two bodies are composed of sand whereas the remaining bodies are shell dominated (bodies 6 to 9 are exclusively constituted of shells; Richiano et al., 2012). The sequential order illustrates the progradational direction of the system at a particular time (Richiano et al., 2012). Minor surfaces correspond to local migration of architectural elements (e.g., like bars) which show variable orientations from east to west (Fig. 8B). These minor surfaces do not reflect the progradation direction of the system. The SfM-MVS methodology was employed to construct a VO of the shell ridges to reconstruct the exact orientation of the nine main surfaces and to model the beach progradation (Fig. 8C and D). In addition, the geometry and scale of the bodies delimited by the main surfaces were used to analyze environmental signals in the sedimentary record associated with relative sea-level changes.

\subsubsection{Dataset and results}

The Holocene shell ridges from Bahia Samborombón occur as relict crests parallel to the present coastline, with a maximum thickness of 

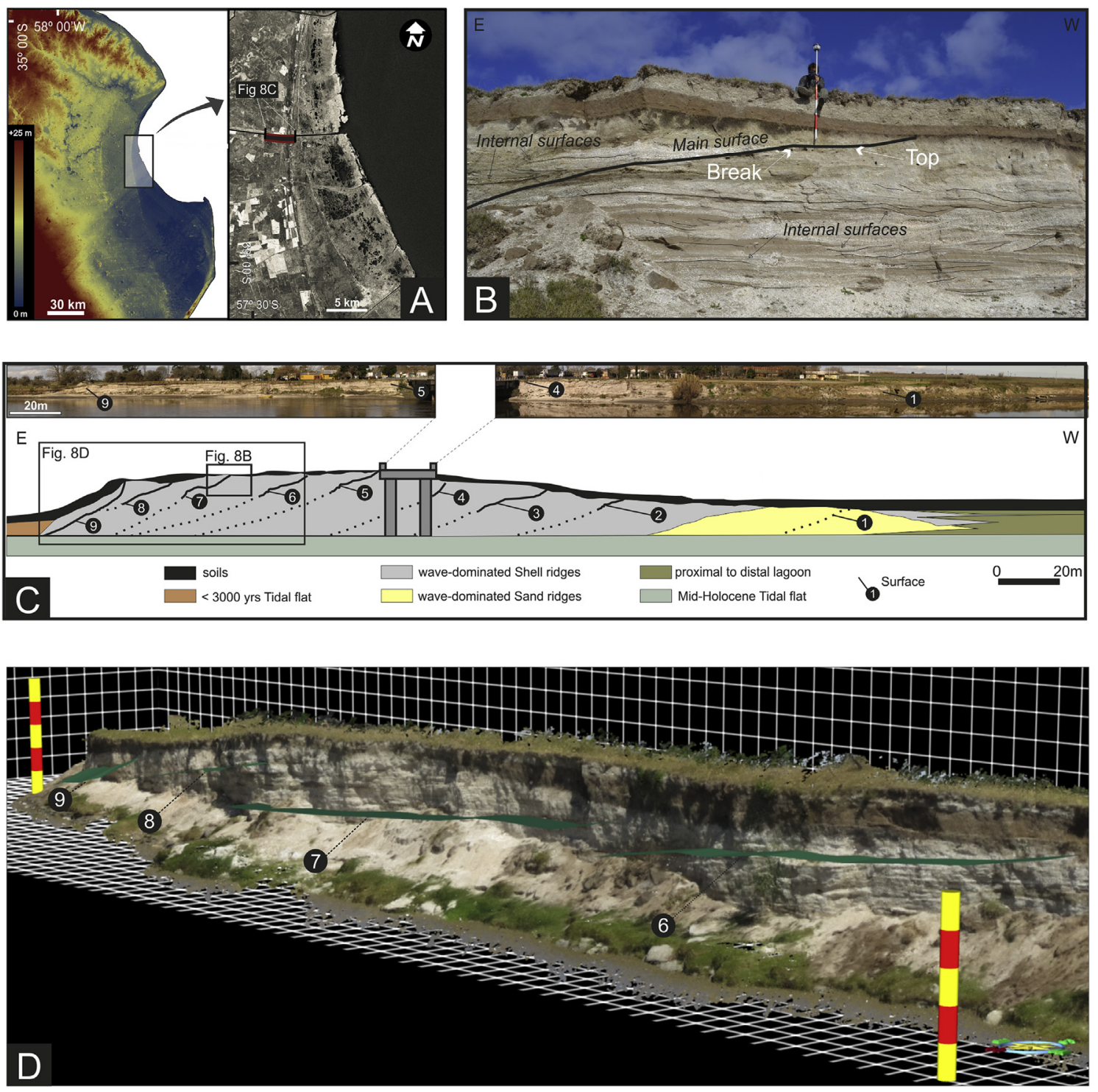

Fig. 8. Case Study 2- Beach ridges of the Bahía Samborombón. A. Location of the study area. The left image is a digital elevation model constructed from elevation data SRTM 3 arc-second resolution. The figure on the right is an image ALOS PRISM with $2.5 \mathrm{~m}$ spatial resolution. B. Outcrop picture of the beach ridge. The thick black lines indicate the main surfaces (i.e., surface 7) and the thin black lines indicate internal surfaces. Top and break zones of the main surface are also indicated. Jacob staff is $2 \mathrm{~m}$. C. Photomosaic and architectural scheme for the littoral ridge. D. 3D virtual outcrop model interpretation. Coloured circles indicate the location of strike and dip measurements of surfaces 6, 7, 8 and 9 (Scale bar $5 \mathrm{~m}$ ).

$6 \mathrm{~m}$ and extending for a $100 \mathrm{~km}$ in N-S direction and up to $300 \mathrm{~m}$ in an E-W direction (Fig. 8B and C). Internally, it is possible to recognize surfaces of different hierarchical orders. The analysis of the 3D shape virtual outcrop allowed measuring the nine major hierarchy surfaces of the shell ridge. These major surfaces were mapped in the VO as polylines, paying special attention to select non-planar portions of the exposures in order to optimize measurement of the correct orientation of the surface (Fig. 8C and D and 9). The geometries of the surfaces are flat to sigmoidal which extend from 6 to $47 \mathrm{~m}$ in the horizontal (Fig. 9A). As the strike of the surfaces is oblique to the outcrop, the values of apparent horizontal extension were corrected to true distance using the average dip direction (Fig. 9A). A combination of bedding measurements and calculation of the best-fit planes for each of the polylines was used to determine the main direction of accretion for the shell ridge. This direction was identified as northeast (N34 ${ }^{\circ}-\mathrm{N} 68^{\circ}$; Fig. 9B). In order to evaluate the change of geometry between the limiting-surfaces, bed attitudes were measured in the top, middle and lower part of lithosomes (i.e., top, break and bottom to clinoform-shape surfaces see Fig. 9B). The root-mean-square error (RMSE) of the VO calculated using checkpoints is $0.24 \mathrm{~cm}$ (Table 1). For the scale of the clinoforms analyzed, this accuracy guarantees not to have an error greater than $5^{\circ}$ in dip and dip azimuth measurements (Three-Point Problem; MartinezTorres et al., 2012).

The virtual outcrop allowed to measure changes in the slopes of each surface, especially in the break upper roll-over point, where the changes are important for interpretations. In Fig. 9A the surfaces are distributed following a linear pattern, which could be interpreted as the result of a gradual change between them. Surfaces 1 to 8 are characterized by long and short horizontal extension with low break angles (Fig. 9A). In contrast, Surface 9 has a short horizontal extension and high break angles of $c a .15^{\circ}$ (Fig. 9A). The abrupt change identified between surfaces 1 to 8 and surface 9 , could be related to the A/S ratio (accommodation space to sediment supply) through time in the littoral environment as was interpreted in different contexts by different authors (e.g. Driscoll and Karner, 1999; Patruno et al., 2015).

First flat long clinoforms suggest that sand supply was in equilibrium to accommodation space created by the sea-level rise. Between surfaces 1 and 5 , this was the prevailing condition, even when the 

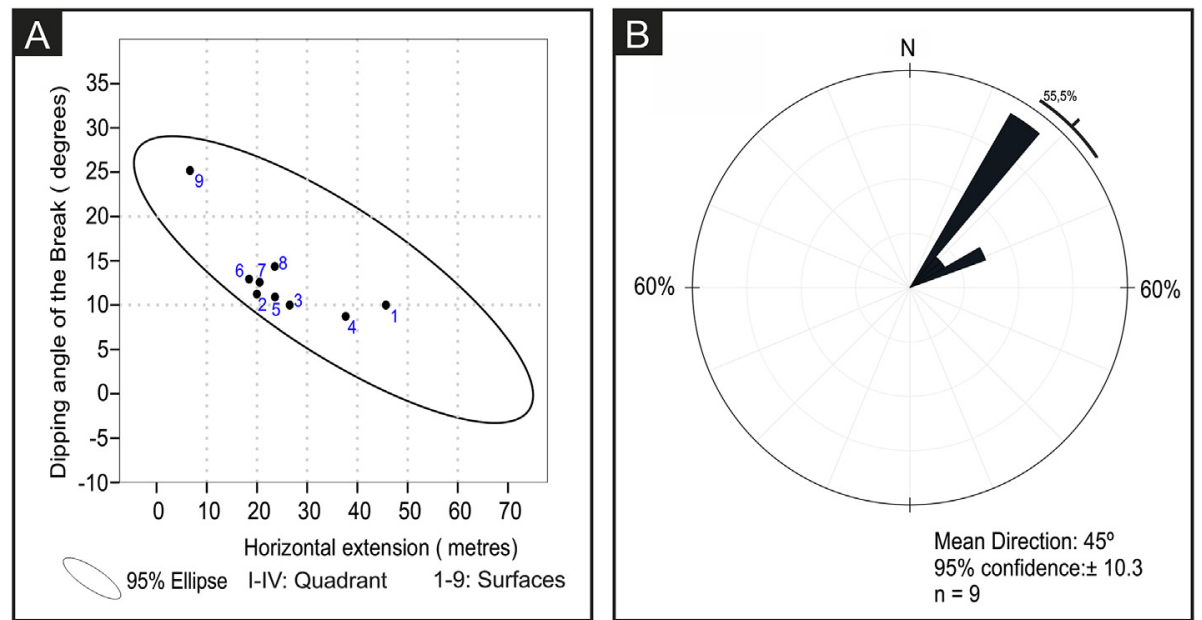

Fig. 9. A. Break slope versus horizontal extension of internal bodies of the littoral ridge. B. Dip direction of the major internal bodies of the littoral ridge at the study area.

sediment supply abruptly changed from purely siliciclastic to merely bioclastic (Fig. 8C). Afterward, during the generation of surfaces 6 to 8 , the sediment supply (exclusively shells) was higher than the decreasing accommodation space due to the relative sea-level fall resulting in the formation of sigmoidal short surfaces. Finally, surface 9 represents the abandonment of the marine system after a major relative sea-level fall. Summarising, the 3D analysis carried out allowed us: (i) to identify a northwards direction of the littoral derive, confirming one of the working hypothesis; (ii) to generate a model for each surface allowing to interpret the progradation sequence of the littoral systems throughout time; and (iii) to determine two groups of limiting-surfaces, divided by the balance between autocyclic (erosion/deposition/aggradation relationship) and allocyclic processes (relative sea-level change).

\subsection{Case study 3 (C3): lake level fluctuations in a range of 50 years}

Lake level in hydrologically closed basins is highly sensitive to climate change. Lacustrine successions provide excellent records of past climate and climate changes. The Patagonian Foreland includes several closed troughs filled with Neogene-Quaternary clastic deposits that nowadays are organized in different closed-basins containing lacustrine systems (e.g. Lago Cardiel, Laguna Carri Laufquen Grande, Lago Muster-Colhue Huapi; Fig. 3). All these lakes present several subaerial exposed shorelines (i.e., gravelly beach-ridges) in their eastern side that preserve the most recent changes in lake level from the Pleistocene to present-day (Galloway et al., 1988; Ariztegui et al., 2001; Gilli et al., 2005; Del Valle et al., 2007; Cartwright et al., 2011; Bilmes et al., 2017, Fig. 10A). The catchment areas of these drainage networks are decoupled from present glacial meltwater input (Rabassa and Clapperton, 1990), and observed changes in the lake level history are mostly due to changes in precipitation and/or evaporation over the basin. In addition, recent investigations based on satellite images suggest that these Patagonian Foreland lakes have significantly fluctuated throughout the past 50 years in response to meteorologically recorded changes in climate (DPA, 2012; Llanos et al., 2014; Scordo et al., 2017).

Laguna Carri Laufquen Grande, located in the intermontane Maquinchao Basin at around 780 masl, is the most northeasterly closed basin lake of the Patagonian Foreland (Coira, 1979; Del Valle et al., 2007; Bilmes et al., 2017, Figs. 3 and 10). The dimensions of this lake fluctuate greatly, from a water surface area of $20-55 \mathrm{~km}^{2}$ and an average water depth of $3 \mathrm{~m}$ (Ariztegui et al., 2001, 2008; DPA, 2012; Hunger, 2012, Fig. 10B). The total catchment area is ca. $10,700 \mathrm{~km}^{2}$ with the ephemeral Río Maquinchao as the principal inflowing river (Fig. 10A). The lake and its catchment area lie in an arid to semiarid region with a mean annual precipitation of $171 \mathrm{~mm}$ and a mean annual temperature of $10^{\circ} \mathrm{C}$ (1965-2016 series Argentinean Meteorological Survey, DPA). Rainfall is limited and highly variable in space and time falling primarily in Austral winter months (May to August). However, extreme precipitation events may occur at any time of the year (e.g., maximum monthly pluvial precipitation of the past 50 years was registered in April 2014, Fig. 11A). Mean monthly temperatures range from $1{ }^{\circ} \mathrm{C}$ to $20^{\circ} \mathrm{C}$ in the Austral winter and summer seasons, respectively, and the prevailing winds are from the west. Previous research in this lake indicated substantial base-level fluctuations in the last decades in response to climate variations (Cartwright et al., 2011; DPA, 2012). Unfortunately, lake levels in Laguna Carri Laufquen Grande, as most Patagonian lakes, are not monitored and thus lake level fluctuations were not continuously recorded during the last century and need to be determined by indirect means.

Several pristine gravelly beach ridges are exposed above the present lake level along more than $2 \mathrm{~km}$ in the Eastern margin of Laguna Carri Laufquen Grande close to the inflowing of the Río Maquinchao (Fig. 10C-F). Because these coastal deposits formed in response to fluctuations in lake level, they can be used to reconstruct lake-level changes during times when instrumental data are not available. The SfM-MVS methodology was employed to obtain a high-resolution geometry and position of the lake palaeoshorelines (i.e., a high-resolution digital terrain model of the eastern margin of the Laguna Carrilaufquen, Fig. 10F). These data, together with the interpretation of multitemporal satellite images were further used to reconstruct the magnitude and frequency of Laguna Carri Laufquen Grande lake level variations for the past 44 years. In addition, these lake levels were contrasted with local rain records in order to analyze the environmental signals associated with these lake level fluctuations.

\subsubsection{Dataset and results}

Spatial data manipulations and analysis were carried out in ArcGIS 10.1. The DEM was constructed following the SfM-MVS methodology described previously and was used to determine the geometry and position ( $\mathrm{x}, \mathrm{y}$, and $\mathrm{z}$ ) of the gravelly-beach ridges. To test the accuracy of the model, validation was performed by a point-to-raster comparison of height values (See section 2.3; Supplementary data). This comparison indicates a mean difference of $0.02 \mathrm{~cm}$ and ranges between $-0.13-0.15 \mathrm{~cm}$ (Fig. 5c, Supplementary data), giving an accuracy of the SfM-MVS DEM of around $\pm 0.15 \mathrm{~cm}$.

Twenty-three satellite images (Landsat 5, 8, SPOT 6, 7 and Google Earth imagery) from 1973 to 2016 were used to provide information on the lake shorelines position at various times. The majority of these images were recorded during the Austral summer season 

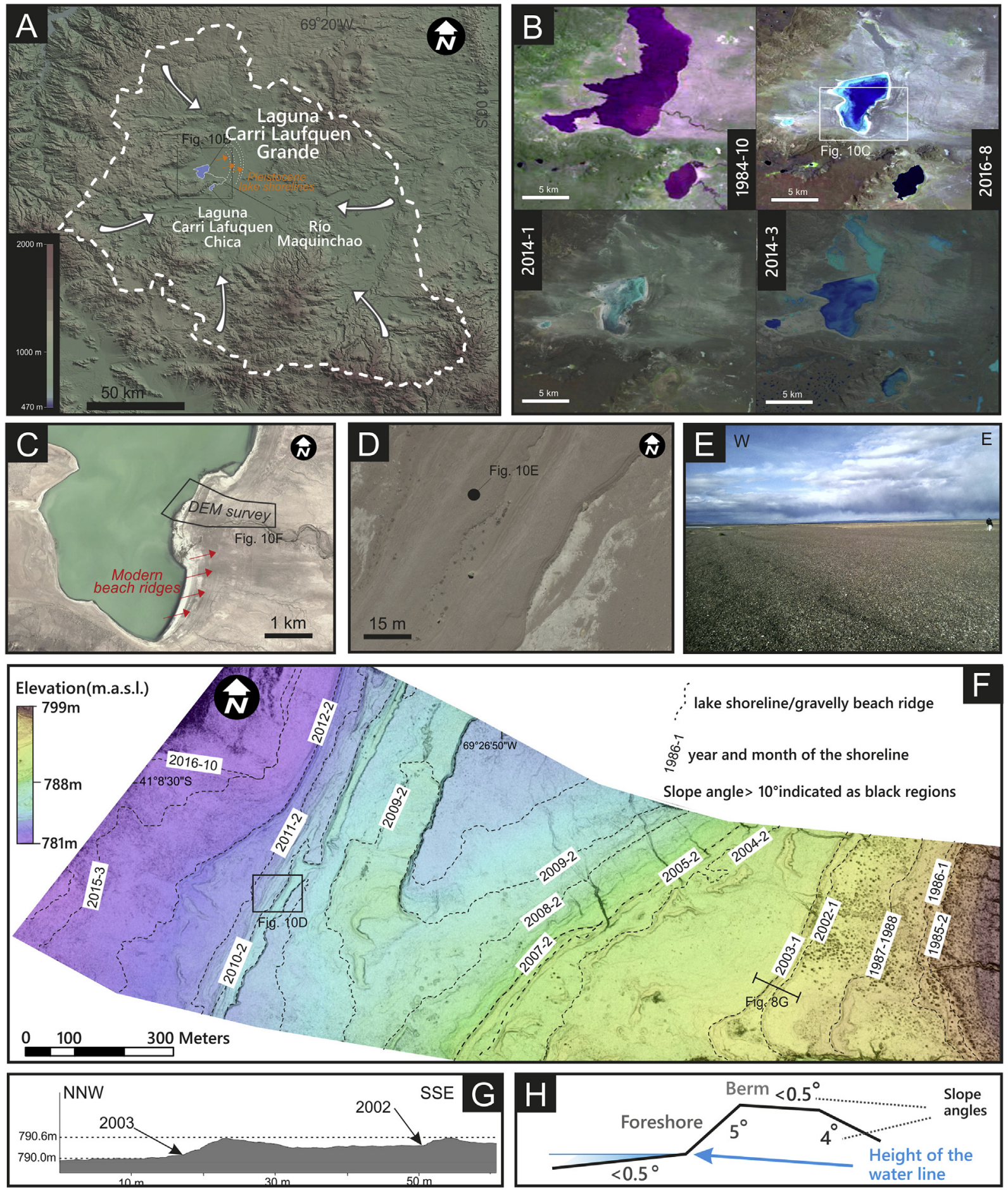

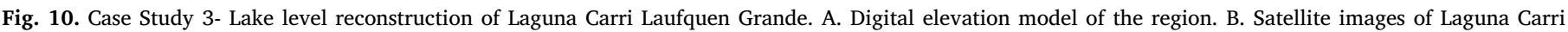

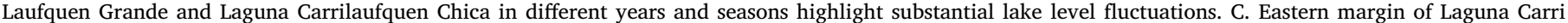

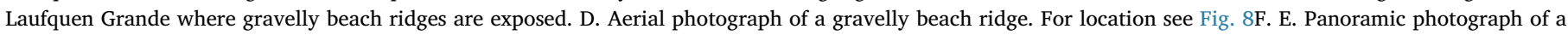

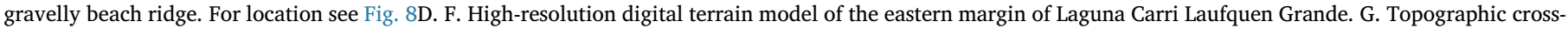
section of two gravelly beach ridges, see Fig. $8 \mathrm{~F}$ for location. H. Summary cross section of gravelly beach ridges of Laguna Carri Laufquen Grande.

(December-April) with the exception of 2014 which was the wettest year in the past 50 years. For this year four images were analyzed (i.e., one for each season, Fig. 10B). Two procedures for lake level reconstruction were performed depending on the spatial resolution of the satellite images. When the available imagery had a spatial resolution of less than $1 \mathrm{~m}$ (i.e., SPOT 7 and Google Earth imagery) water level position was determined directly using the height of the DTM that match with the water line position in the image. When the satellite images had a spatial resolution greater than $1 \mathrm{~m}$ (i.e., Landsat, 5, 8, SPOT 6), the historic water level position was interpreted by analysing the position of the shoreline zone of the image (spatial resolution around 15-30 m) with the geometry of the gravelly-beach ridge identified in that zone. The height of the water line (i.e., approximately the still-water level of the lake) was determined at the point where the foreshore slope 

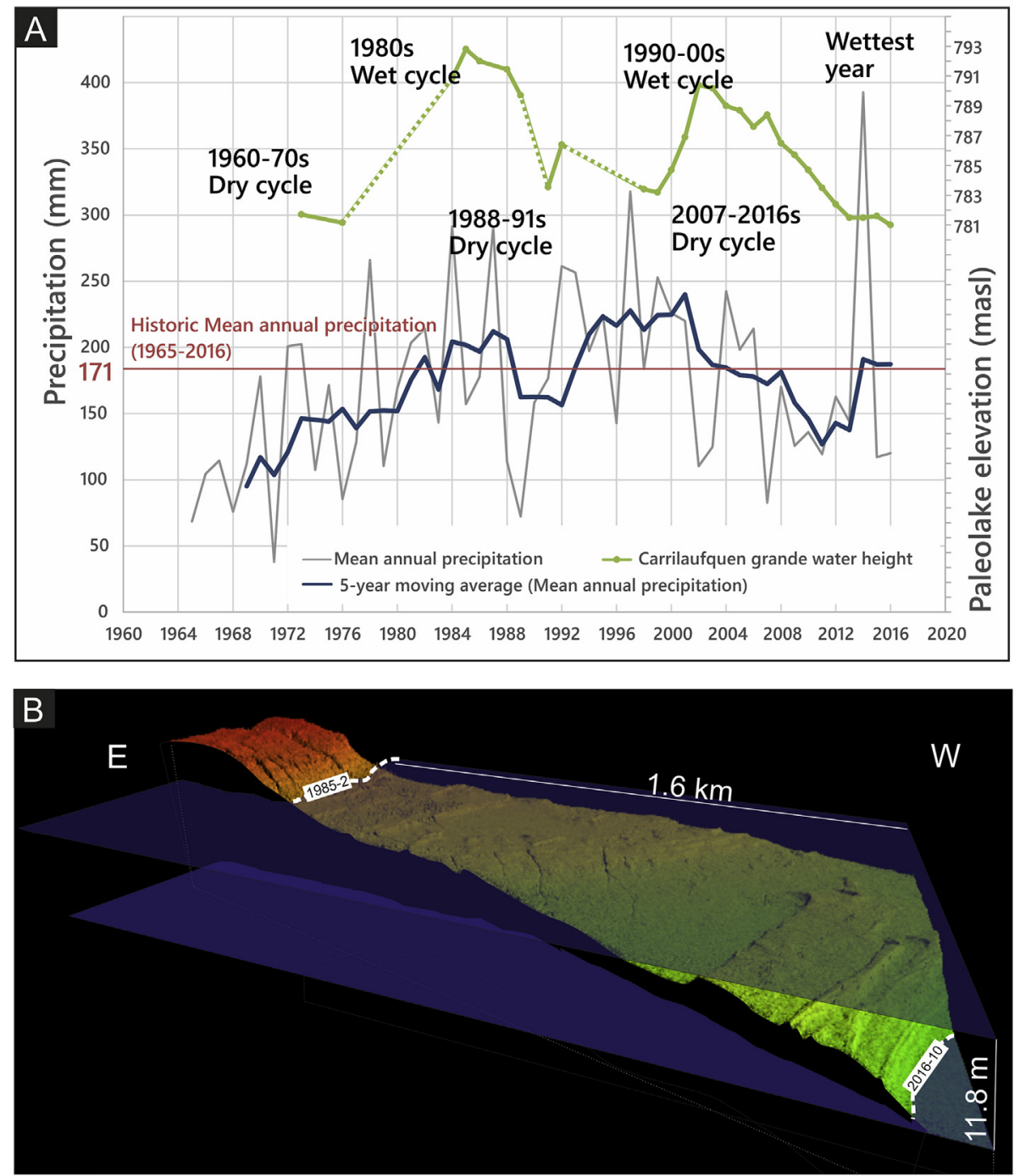

Fig. 11. A. Hydrograph of Laguna Carri Laufquen Grande estimated with the SfM-MVS approach compared to historic mean annual precipitation of the region (1965-2016 series Argentinean Meteorological Survey, DPA). B. 3D visualization of a DTM of the eastern sector of Laguna Carri Laufquen Grande. Lake level maxima and minima of the period 1973-2016 are indicated.

increases its angle, a position frequently located $0.2-1 \mathrm{~m}$ below the landward-inclined uppermost surface of the berm (Fig. 10G and H). This position is interpreted as the transition between the swash zone and the berm.

Our results show that the 2016 lake level was among the lowest lake levels of the past 44 years ( $0 \mathrm{~m}$ in this study), whereas the maximum lake level was recorded in 1985 ( $+11.8 \mathrm{~m}$ above the current lake or above current level; acl) in a position $1.6 \mathrm{~km}$ to the east of the present coastline (Fig. 11A and B). Twenty-eight gravelly beach ridges were observed between these two extreme lake levels. They vary in size and shape (Figs. 10F and 11B). Some of the gravelly beach ridges have a composite appearance showing up to two or three culminations presumably representing several phases of sediment deposition. Their width varies between 10 and $25 \mathrm{~m}$, and the composite beach ridges are between 30 and $150 \mathrm{~m}$ wide (Fig. 10F and G). Estimations for the vertical height based on changes in the shoreline slope range among 20-95 cm (Fig. 10G). A typical topographic cross-section of the gravelly beach ridge from the lake to the land is arranged by: (1) a gently dipping lakeward slope $\left(<1^{\circ}\right)$ interpreted as the swash zone; (2) a steeper lakeward slope with a $5^{\circ}$ angle; (3) a landward-inclined berm top surface dipping less than $0.5^{\circ}$; and (4) a steeper landward slope dipping $4^{\circ}$ that in rare cases could reach up to $11^{\circ}$ (Fig. 10H).

By analysing the hydrography of the Laguna Carri Laufquen Grande
(Fig. 11A) it is possible to observe substantial lake level fluctuations (i.e., 9-11 m magnitude) and discriminate between highstand and lowstand conditions (i.e., 1985, 2002 highstand years/periods and 1973-1976, 1999 and 2016 were lowstand years/periods; Fig. 11A and B). A 5-year moving average rainfall record of the area was calculated smoothing the extreme annual events and correlated to the determined lake level fluctuations (Fig. 11A). The reconstructed lake levels were compared to the average rainfall and a 5 year moving average rainfall record (Fig. 11A). Lake level corresponds more obviously with the 5year average (Fig. 9 and 11A). This could be interpreted as a delay in the response of the lake system that might be influenced by other variables such as groundwater discharge into the lake. The lake level variability within a single year shows that it can fluctuate up to $1.2 \mathrm{~m}$ in response to seasonal patterns or extreme precipitation events (i.e., extreme year of precipitation in 2014; Figs. 10B and 11A).

Applying the technique of SfM-MVS on lake shorelines allowed quantifying lake level changes for the past 44 years in Laguna Carrilaufquen Grande and, in addition, to analyze the response of the system to an extreme event of precipitation. This approach indicates that the annual variation of lake levels was up to $1.2 \mathrm{~m}$ (i.e., April 2014) whereas decadal variations related to humid-arid periods were up to $9.4 \mathrm{~m}$ (i.e. 2002-2016; Fig. 9B). The frequency and magnitude of the lake level fluctuations quantified with this approach are similar to 
Table 2

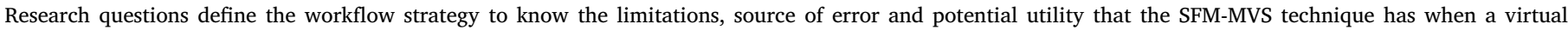
sedimentary system is interpreted. Information for each of the three case studies.

\begin{tabular}{|c|c|c|c|}
\hline & Case 1 & Case 2 & Case 3 \\
\hline RESEARCH QUESTION & $\begin{array}{l}\text { Analyze the relation between the growth of an } \\
\text { anticline mountain front and the infill of the } \\
\text { neighbouring basin }\end{array}$ & $\begin{array}{l}\text { Reconstruct a littoral drift } \\
\text { direction with shell ridge } \\
\text { clinoforms }\end{array}$ & $\begin{array}{l}\text { Quantify lake level fluctuations with gravelly } \\
\text { beach ridges }\end{array}$ \\
\hline Description of key measurements & $\begin{array}{l}\text { Dip-Azimuth strata and strata thick of sedimentary } \\
\text { growth strata }\end{array}$ & $\begin{array}{l}\text { Geometry of the clinoforms (dip } \\
\text { Azimuth, extension and shape) }\end{array}$ & 3D position and shape of beach ridges \\
\hline $\begin{array}{l}\text { The motivation for VO/DTMs } \\
\text { application using SfM-MVS }\end{array}$ & $\begin{array}{l}\text {-Badland terrain without good strata where to take } \\
\text { Dip-Azimuth measures in the field. } \\
\text {-Crest erosion of the anticline and irregular } \\
\text { exposition of the outcrops. }\end{array}$ & $\begin{array}{l}\text { - Outcrops with difficult access } \\
\text {-Sigmoidal surfaces extensions } \\
\text { do not allow to take measures in } \\
\text { the field } \\
\text {-Bodies exposed with apparent } \\
\text { geometries }\end{array}$ & $\begin{array}{l}\text {-Lake with non-available monitoring data demand } \\
\text { a high-resolution DEM of the beach ridges } \\
\text { (shorelines) to reconstruct lake level changes } \\
\text {-Available DEMs in the study region have low } \\
\text { spacial resolution for shoreline analysis }\end{array}$ \\
\hline Technique used & TSfM & TSfM & ASfM \\
\hline Acquisition path strategy & 222 stations & 152 stations & 2 oblique flights \\
\hline Scale of the studied object (m) & $\begin{array}{l}10^{-1} \text { vertical } \\
10^{2} \text { horizontal }\end{array}$ & $\begin{array}{l}10^{-1} \text { to } 10^{1} \text { vertical } \\
10^{1} \text { horizontal }\end{array}$ & $\begin{array}{l}10^{-2} \text { vertical } \\
10^{2} \text { horizontal }\end{array}$ \\
\hline Validation methods & $\begin{array}{l}\text { Direct dip and dip azimuth measurements } \\
\text { comparison with dip and dip azimuth measurements } \\
\text { of the VO using k constant (Fisher et al., 1987) }\end{array}$ & $\begin{array}{l}\text { Point cloud comparison with } \\
\text { field checkpoints derived from } \\
\text { TS }\end{array}$ & $\begin{array}{l}\text { Point-to-raster comparison. Z values from the DEM } \\
\text { (Grid size } 30 \times 30 \mathrm{~cm} \text { ) vs dGPS points. }\end{array}$ \\
\hline
\end{tabular}

historic values documented on monitored closed lakes (e.g., Great Salt Lake magnitude of lake level fluctuation between 0.6 and $2 \mathrm{~m}$ by seasonal patterns and around $7 \mathrm{~m}$ by decadal variability of climate; Atwood et al., 2016). Thus, new perspectives to understand the historical water level fluctuations of lakes with non-available monitoring data could be envisaged using the SfM-MVS approach.

\section{Discussion}

Many sedimentological studies require analysis and interpretation in 3D by using virtual outcrops (VO) and/or high-resolution digital terrain models (DTMs). The results of our investigations demonstrate that different acquisition methods using the SfM-MVS technique can be used to resolve sedimentary questions that were not possible to answer using only standard fieldwork (Table 2). The SfM-MVS approach is used to construct VO or DTMs from which is possible to extract spatial geological information. Examples include detail bed by bed measurement and rebuilding of growth strata of outcrops with difficult access, large-scale beach ridge geometry reconstruction in unconsolidated ridges, and the quantification of lake levels changes in closed lacustrine systems without monitoring data (Table 2). The using of VO or DTMs was essential to resolve these research questions. Outcrop nature and morphology (e.g., badland terrain, unconsolidated material, outcrop discontinuity due to fluvial erosion), limited accesses to them, measurement of large geometries (e.g, sigmoidal geometries with apparent horizontal extension $>40 \mathrm{~m}$ ) and decimeter analysis of landforms (e.g., foreshore slope morphology of a beach ridge) were some of the main problems that prevented data collection with traditional fieldwork techniques and demanded the use of a VO or DEMs.

Similar sedimentological problems described above were resolved in the past decade using VO and DEMs constructed with airborne LiDAR scanning (ALS) or terrestrial laser scanning (TLS), such as quantification of clinoform geometries (Buckley et al., 2008; Enge et al., 2010; Rittersbacher et al., 2014), measurement of stratal geometries (Hodgetts, 2013; Cawood et al., 2017; Muravchik et al., 2017) and detail morphometric analysis of beach ridges (Houser et al., 2008; Zhou and Xie, 2009; Jewell, 2016). The methodological approach of this work demonstrates the possibility to resolve sedimentary problems using VO or DEMs as similar as LIDAR but with an approach that is easier to use and much more accessible and affordable for the sedimentological community. It also shows a workflow to improve VO and DEMs construction, taking into account the acquisition strategy and validation method to design the virtual models. This is important because as it is happening with other disciplines in geosciences (e.g.,
Westoby et al., 2012; Bistacchi et al., 2015; Carrivick et al., 2016) the application of SfM-MVS in sedimentology and basin analysis is increasing exponentially (e.g., Chesley et al., 2017; Nieminski and Graham, 2017; Nesbit et al., 2018). Thus, inevitably, the SfM-MVS approach will turn into a technique of worldwide use in sedimentary and basin analysis studies. Given the possible impact of SfM-MVS on the stratigraphic and sedimentological community and the large number of potential users of this technique, it is important to understand its limitations and potential pitfalls. Several studies have shown that SfM-MVS 3D models have less consistency than those generated by LIDAR (Sturzenegger and Stead, 2009; James and Robson, 2012; Westoby et al., 2012; Cawood et al., 2017). The workflow used in this contribution, both with Terrestrial SfM-MVS (i.e., case 1 and 2) and Aerial SfM-MVS (i.e., case 3) maximizes the photo coverage, convergent imagery and synoptic viewpoints, allowing a high tie-point location that it is a critical step in the 3D model construction (James and Robson, 2012). Previous work indicated that the quality of VO derived from Terrestrial SfM (TSfM), is inferior to VO derived from Aerial SfM (ASfM) UAV imagery because the difficulty to access to close-range imagery from a number of angles (Cawood et al., 2017). In the work of Cawood et al. (2017) the outcrop inaccessibility implicated that images (i.e., 446 photos) were taken from semi-synoptic viewpoints only from 25 positions. In comparison, in the two case studies of this work were TSfM was applied (cases 1 and 2, respectively), the outcrop accessibility following a careful photo acquisition (see section 2.1), allowed obtaining a high quantity of convergent overlapping imagery (i.e., 405 images and 161 images, respectively) from multiple positions (220 positions and 152 positions, respectively; Table 1, Fig. 4). As a result, more than 9 overlapping images were used for generating each tie-point during TSfM processing (compared to between 2 and 6 for TSfM in Cawood et al., 2017). Thus, point coordinate estimation was performed in all the regions of the model with a high number of images, improving final VO accuracy. This increase in convergent image overlap by increase photo acquisition stations implicates that reconstructions using even TSfM could be strongly improved following a careful photo acquisition in cases of good outcrop accessibility.

Irrespective of the survey planning and photo acquisition technique described above, the quality assessment of the $3 \mathrm{D}$ model is cautious to ensure reliable geological interpretations. Previous work demonstrated that the accuracy of VO and DEMs using SfM-MVS reconstructions is overestimated when is quantified only using control points, with nonvalidation using independent checkpoints or measured bedding orientations (Carrivick et al., 2016; Cawood et al., 2017; Sanz-Ablanedo et al., 2018). In this work, different validation techniques were applied 
and include comparison of field data versus VO data of bedding orientations in key control surfaces (Case 1, see section 2 and 3.1, Table 2) and a comparison of point cloud derived from SfM-MVS with checkpoints derived directly from TS or dGPS (cases 2 and 3, respectively).

Validation of VO and DEMs of this work confirms that the accuracy of the model is overestimated when it is quantified using only control points, without checkpoints (i.e., ground control points not used to georeferenced the model). For example, in case 2, the RMSE quantified using checkpoints is nearly 3 times bigger than the RMSE quantified using only control points, whereas in Case 3 , the final accuracy of the model is nearly seven times larger than the RMSE calculated using only control points (Supplementary data). The validation of the models determines their quality and limitations to extract geological information. The last point has substantial implications for VO and DTMs interpretations because it would determine if the quality of the model is correct for the purposes of the study, which are determined by the size of the studied object in addition to the required data accuracy. For example, the results of VO validation of case 2 determine that the VO is suitable to interpret the main surfaces that define the limits of each unit, but it is not enough for the analysis of their internal architectural elements (Fig. 8, Table 2). Even though, the results obtained in this work indicate that a different acquisition strategy would have been useful to solve this problem in order to increase the overlapping images, achieving a low rate of $\mathrm{N}$ images/ $\mathrm{N}$ camera positions to improve the resolution of the model. For instance, for case study 1 the Fisher mean vector and the dispersion of measures obtained are similar to those achieved in VO constructed with ASfM or LIDAR (see Cawood et al., 2017). It is important to point out that, as stressed in previous works using VO or DEM constructed either with LIDAR or SFM-MVS (Bellian et al., 2005; Rarity et al., 2014; Carrivick et al., 2016), 3D models can improve our current field methods. While they can help to quantify many observations made by the geologist in the field they cannot fully replace them.

Finally, it is important to emphasize that although survey planning and acquisition strategy are important, photo acquisition technique and quality assessment of the 3D model are mandatory to construct more reliable VO or DEMs using the SfM-MVS approach. As it happens with 3D reconstructions using LIDAR, if the geometry of the outcrops is poorly represented, the quality of the interpretations and measures may be inaccurate and poorly reliable. Thus, the nature of the outcrop determines our capacity in interpreting it.

\section{Summary and conclusions}

The three case studies presented here demonstrate that the use of the SfM-MVS technique can provide new solid quantitative information for the analysis and interpretation of virtual outcrops (VO) or highresolution digital terrain models (DTMs). Although SfM-MVS models normally have less consistency than those generated by airborne and terrestrial LIDAR, this contribution demonstrates how 3D reconstructions could be improved with survey planning, photo acquisition techniques and validation using field data. Our results show that the SfM-MVS technique is a robust approach to collect data from areas with difficult access as well as to increase the precision and sample size of direct measurements from an outcrop (e.g., width, thickness, strike and dip). These characteristics ensure that the SfM-MVS methodology not only substantially improves the analysis of sedimentary geoforms but also allows moving forward with still unanswered questions related to modern and ancient sedimentary systems.

\section{Acknowledgements}

The authors would like to thank the inhabitants of the study area for their support and hospitality. We are especially grateful to Daniela Funes, Carolina Cuevas, Juan Gabriel Vazquez, Mariano Gonzalez
Dobra and Fernando Suarez for their assistance in the field as well as to Sam Carmalt for English proof-reading. SPOT images were provided for free by the CONAE. The VRGS academic license for this work was generously offered by David Hodgetts. This research was funded by the CONICET (PIP 5968, PIP 0632) and the Swiss National Science Foundation (SNF 200021_155927). Cecilia del Papa and an anonymus reviewer are greatly appreciated for the corrections made to the original manuscript.

\section{Appendix A. Supplementary data}

Supplementary data to this article can be found online at https:// doi.org/10.1016/j.jsames.2019.102325.

\section{References}

Allmendinger, R.W., Jordan, T.E., Kay, S.M., Isacks, B.L., 1997. The evolution of the Altiplano-Puna plateau of the central andes. Annu. Rev. Earth Planet Sci. 25, $139-174$.

Anadón, P., Cabrera, L., Colombo, F., Marzo, M., Riba, O., 1986. Syntectonic intraformational unconformities in alluvial fan deposits, Eastern Ebro Basin margins (NE Spain). In: In: Allen, A., Homewood, P. (Eds.), Foreland Basins- International Association of Sedimentologists, Special Publication, vol. 8. Blackwell Scientific Publications, pp. 259-271.

Ariztegui, D., Anselmetti, F.S., Kelts, K., Seltzer, G., D'Agostino, A., 2001. Identifying paleoenvironmental change across South and North America using high-resolution seismic stratigraphy in lakes. In: Markgraf, V. (Ed.), Interhemispheric Climate LinkAges. Academic Press, San Diego, pp. 227-240.

Ariztegui, D., Anselmetti, F.S., Gilli, A., Waldmann, N., 2008. Late Pleistocene environmental change in Eastern Patagonia and Tierra del Fuego - a Limnogeological approach. In: Rabassa, J. (Ed.), The Late Cenozoic of Patagonia and Tierra Del Fuego Developments in Quaternary Sciences Series. Elsevier, pp. 241-253.

Atwood, G., Wambeam, T.J., Anderson, N.J., 2016. The present as a key to the past: paleoshoreline correlation insights from Great Salt Lake. In: Oviatt, C., Shroder, J. (Eds.), Lake Bonneville: A Scientific Update. Elsevier, pp. 1-27.

Bellian, J.A., Kerans, C., Jennette, D.C., 2005. Digital outcrop models: applications of terrestrial scanning LiDAR technology in stratigraphic modeling. J. Sediment. Res. 75, 166-176.

Bilmes, A., D'Elia, L., Franzese, J.R., Veiga, G.D., Hernández, M., 2013. Miocene block uplift and basin formation in the Patagonian foreland: the Gastre Basin, Argentina. Tectonophysics 601, 98-111.

Bilmes, A., Veiga, G.D., Ariztegui, D., Castelltort, S., D'Elia, L., Franzese, J.R., 2017. Quaternary base-level drops and trigger mechanisms in a closed basin: geomorphic and sedimentological studies of the Gastre Basin, Argentina. Geomorphology 283, $102-113$.

Bistacchi, A., Balsamo, F., Storti, F., Mozafari, M., Swennen, R., Solum, J., Tueckmantel, C., 2015. Photogrammetric digital outcrop reconstruction, visualization with textured surfaces, and three-dimensional structural analysis and modeling: innovative methodologies applied to fault-related dolomitization (Vajont Limestone, Southern Alps, Italy). Geosphere 6 2031-2048.

Boufama, B., Weinshall, D., Werman, M., 1994. Shape from motion algorithms: a com parative analysis of scaled orthography and perspective. Comput. Vis._ECCV 94, 197-204.

Brimhall, G.H., Vanegas, A., Lerch, D., 2002. GeoMapper program for paperless field mapping with seamless map production in ESRI ArcMap and Geo Logger for drill-hole data capture: applications in geology, astronomy, environmental remediation, and raised-relief models. US Geol. Surv. Open-File Rep. 2, 141-151.

Brodaric, B., 1997. Field data capture and manipulation using GSC FIELDLOG v3. 0. In: Proceedings of a Workshop on Digital Mapping Techniques: Methods for Geologic Map Capture, vol. 97. Management and Publication. US Geological Survey, Open File Report, pp. 77-81 269.

Buckley, S.J., Howell, J.A., Enge, H.D., Kurz, T.H., 2008. Terrestrial laser scanning in geology: data acquisition, processing and accuracy considerations. J. Geol. Soc. Lond. $165,625-638$.

Carrivick, J.L., Smith, M.W., Quincey, D.J., 2016. Structure from Motion in the Geosciences. John Wiley \& Sons, pp. 197.

Cartwright, A., Quade, J., Stine, S., Adams, K.D., Broecker, W., Cheng, H., 2011. Chronostratigraphy and lake-level changes of Laguna Cari-Laufquén, Río Negro, Argentina. Quat. Res. 76, 430-440.

Cawood, A.J., Bond, C.E., Howell, J.A., Butler, R.W.H., Totake, Y., 2017. LiDAR, UAV or compass-clinometer? accuracy, coverage and the effects on structural models. J. Struct. Geol. 98, 67-82.

Chesley, J.T., Leier, A.L., White, S., Torres, R., 2017. Using unmanned aerial vehicles and structure-from-motion photogrammetry to characterize sedimentary outcrops: an example from the Morrison Formation, Utah, USA. Sediment. Geol. 354, 1-8.

Clegg, P., Bruciatelli, L., Domingos, F., Jones, R.R., De Donatis, M., Wilson, R.W., 2006. Digital geological mapping with tablet PC and PDA: a comparison. Comput. Geosci. 32, 1682-1698.

Codignotto, J.O., Aguirre, M.L., 1993. Coastal evolution, changes in sea level and molluscan fauna in northeastern Argentina during the Late Quaternary. Mar. Geol. 110, $163-175$. 
Coira, B.L., 1979. Descripción geológica de la Hoja 40 d, Ingeniero Jacobacci. Servicio Geológico Nacional, pp. 101.

Del Valle, H.F., Tatur, A., Rinaldi, C.A., 2007. Cambios en lagos y circulación fluvial vinculados al calentamiento climático del Pleistoceno tardío-Holoceno temprano en Patagonia e Isla 25 de mayo, islas shetland Del sur, Antártida. Rev. Asoc. Geol. Argent. 62, 618-626.

D'Elia, L., Muravchik, M., Bilmes, A., Franzese, J., Hernandez, M., 2008. Análisis estratigráfico y sedimentológico de las unidades de acumulación mio-pliocenas del suroeste de la provincia de Neuquén. San Salvador de Jujuy. In: Proceedings XVII Congreso Geológico Argentino, vol. 2. pp. 1003-1004.

DPA, 2012. Informe Lagunas Carri-Laufquen. DPA, pp. 26.

Driscoll, N.W., Karner, G.D., 1999. Three-dimensional quantitative modeling of clinoform development. Mar. Geol. 154, 383-398.

Enge, H.D., Buckley, S.J., Rotevatn, A., Howell, J.A., 2007. From outcrop to reservoir simulation model: workflow and procedures. Geosphere 3, 469-490.

Enge, V.D., Howell, J.A., Buckley, S., 2010. Quantifying clinothem geometry in a forcedregressive river- dominated delta, Panther Tongue Member, Utah, USA. Sedimentology 57, 1750-1770.

Fabuel-Perez, I., Hodgetts, D., Redfern, J., 2010. Integration of digital outcrop models (DOMs) and high resolution sedimentology - workflow and implications for geological modelling: Oukaimeden Sandstone Formation, High Atlas (Morocco). Pet. Geosci. 16, 133-154.

Fisher, N.I., Lewis, T., Embleton, B.J.J., 1987. Statistical Analysis of Spherical Data. Cambridge University Press, pp. 339.

Fonstad, M.A., Dietrich, J.T., Courville, B.C., Jensen, J.L., Carbonneau, P.E., 2013. Topographic structure from motion: a new development in photogrammetric measurement. Earth Surf. Process. Landforms 38, 421-430.

Franzese, J.R., D'Elia, L., Bilmes, A., Bucher, J., García, M., López, M., Muravchik, M., Hernández, M., 2018. Evolution of a patagonian miocene intermontane basin and its relationship with the andean foreland: tectono-stratigraphic evidences from the Catán Lil Basin, Argentina. J. South Am. Earth Sci. 86, 162-175.

Frenguelli, J., 1950. Rasgos generales de la morfología y de la geología de la provincia de Buenos Aires. Laboratorio de Entrenamiento Multidisciplinario para la Investigación Tecnológica, La Plata. Serie 2 (30), 72.

Furukawa, Y., Ponce, J., 2007. Accurate, dense, and robust multi-view stereopsis. In: IEEE Computer Society Conference on Computer Vision and Pattern Recognition, https:// doi.org/10.1109/CVPR.2007.383246.

Galloway, R.W., Markgraf, V., Bradbury, J.P., 1988. Dating shorelines of lakes in Patagonia, Argentina. J. South Am. Earth Sci. 1, 195-198.

García Morabito, E., Ramos, V.A., 2012. Andean evolution of the Aluminé fold and thrust belt, northern patagonian andes $\left(38^{\circ} 30^{\prime}-40^{\circ} 30^{\prime} \mathrm{S}\right)$. J. South Am. Earth Sci. 38, 13-30.

García- Morabito, E.G., Götze, H.J., Ramos, V.A., 2011. Tertiary tectonics of the Patagonian Andes retro-arc area between $38^{\circ} 15^{\prime}$ and $40^{\circ} \mathrm{S}$ latitude. Tectonophysics $499,1-21$.

Gawthorpe, R., Hardy, S., 2002. Extensional fault-propagation folding and base-level change as controls on growth-strata geometries. Sediment. Geol. 146, 47-56.

Gilli, A., Anselmetti, F.S., Ariztegui, D., Beres, M.I., Mckenzie, J.A., Markgraf, V., 2005. Seismic stratigraphy, buried beach ridges and contourite drifts: the Late Quaternary history of the closed Lago Cardiel basin, Argentina ( $49^{\circ} \mathrm{S}$ ). Sedimentology 52, 1-23.

Harwin, S., Lucieer, A., 2012. Assessing the accuracy of georeferenced point clouds produced via multi-view stereopsis from Unmanned Aerial Vehicle (UAV) imagery. Remote Sens. 4, 1573-1599.

Hirschmüller, H., 2008. Stereo processing by semiglobal matching and mutual information. IEEE Trans. Pattern Anal. Mach. Intell. 30, 328-341.

Hodgetts, D., 2009. LiDAR in the environmental sciences: geological applications. In: Heritage, G., Large, A. (Eds.), Laser Scanning for the Environmental Sciences. WileyBlackwell, Oxford, pp. 165-179.

Hodgetts, D., 2013. Laser scanning and digital outcrop geology in the petroleum industry: a review. Mar. Pet. Geol. 46, 335-354.

Hodgetts, D., Drinkwater, N.J., Hodgson, J., Kavanagh, J., Flint, S.S., Keogh, K.J., Howell, J.A., 2004. Three-dimensional geological models from outcrop data using digital data collection techniques: an example from the Tanqua Karoo Depocentre, South Africa. Geol. Soc. Lond. Spec. Publ. 239, 57-75.

Houser, C., Hapke, C., Hamilton, S., 2008. Controls on coastal dune morphology, shoreline erosion and barrier island response to extreme storms. Geomorphology 100, 223-240.

Howell, J.A., Martinius, A.W., Good, T.R., 2014. The Application of Outcrop Analogues in Geological Modelling: a Review, Present Status and Future Outlook, vol. 387. Geological Society of London, Special Publications, pp. 1-25.

Hunger, G., 2012. Reconstruction paléoenvironnementale du Pleistocène sup.-Holocène au Nord de la Patagonie basée sur les lacs endoréiques Cari-Laufquen, étude des lignes de côtes et stromatolites associés. Université de Genève, pp. 129 Master Thesis.

James, M.R., Robson, S., 2012. Straightforward reconstruction of 3D surfaces and topography with a camera: accuracy and geoscience application. J. Geophys. Res.: Earth Surface $117,1-17$.

James, M.R., Robson, S., 2014. Mitigating systematic error in topographic models derived from UAV and ground-based image networks. Earth Surf. Process. Landforms 39 (10), 1413-1420.

James, M.R., Robson, S., d'Oleire-Oltmanns, S., Niethammer, U., 2017. Optimising UAV topographic surveys processed with structure-from-motion: ground control quality, quantity and bundle adjustment. Geomorphology 280, 51-66.

Javernick, L., Brasington, J., Caruso, B., 2014. Modeling the topography of shallow braided rivers using Structure-from-Motion photogrammetry. Geomorphology 213, $166-182$.

Jewell, P.W., 2016. Geomorphology quantitative identification of erosional lake Bonneville shorelines, Utah. Geomorphology 253, 135-145.
Jones, R.R., McCaffrey, K.J.W., Clegg, P., Wilson, R.W., Holliman, N.S., Holdsworth, R.E., Waggott, S., 2009. Integration of regional to outcrop digital data: 3D visualisation of multi-scale geological models. Comput. Geosci. 35, 4-18.

Llanos, E., Behr, S., Gonzalez, J., Colombani, E., Buono, G., 2014. Informe de las Variaciones del Lago Colhue Huapi mediante sensores remotos y su relación con las precipitaciones. Informe INTA 71, 8.

Marjoribanks, R., 2010. Geological Methods in Mineral Exploration and Mining, second ed. Springer-Verlag Berlin Heidelberg, pp. 233.

Martinez-Torres, L.M., Lopetegui, A., Eguiluz, L., 2012. Computers \& Geosciences Automatic resolution of the three-points geological problem. Comput. Geosci. 42, 200-202.

McCaffrey, K.J.W., Jones, R.R., Holdsworth, R.E., Wilson, R.W., Clegg, P., Imber, J., Trinks, I., 2005. Unlocking the spatial dimension: digital technologies and the future of geoscience fieldwork. J. Geol. Soc. 162, 927-938.

Micheletti, N., Chandler, J.H., Lane, S.N., 2015. Structure from motion (SfM) photogrammetry. Geomorphol. Techn. 2, 1-12.

Muravchik, M., Gawthorpe, R.L., Sharp, I.R., Rarity, F., Hodgetts, D., 2017. Sedimentary environment evolution in a marine hangingwall dipslope setting. El Qaa Fault Block, Suez Rift, Egypt. Basin Res. 28, 1-27.

Nesbit, P.R., Durkin, P.R., Hugenholtz, C.H., Hubbard, S.M., Kucharczyk, M., 2018. 3-D stratigraphic mapping using a digital outcrop model derived from UAV images and structure-from-motion photogrammetry. Geosphere 14, 1-18.

Nieminski, N.M., Graham, S.A., 2017. Modeling stratigraphic architecture using small unmanned aerial vehicles and photogrammetry: examples from the Miocene East Coast Basin, New Zealand. J. Sediment. Res. 87, 126-132.

Otvos, E.G., 2000. Beach ridges-definitions and significance. Geomorphology 32 (1), 83-108.

Patruno, S., Hampson, G.J., Jackson, C.A.L., Whipp, P.S., 2015. Quantitative progradation dynamics and stratigraphic architecture of ancient shallow-marine clinoformsets: a new method and its application to the Upper Jurassic Sognefjord Formation, Troll Field, offshore Norway. Basin Res. 27, 412-452.

Pavlis, T.L., Mason, K.A., 2017. The new world of 3D geologic mapping. GSA Today 27, 4-10.

Poblet, J., 2012. 2D kinematic models of growth fault-related fold. In: Allen, P.A., Allen, J.R. (Eds.), Tectonics of Sedimentary Basins: Recent Advances. Wiley-Blackwell, Oxford, pp. 538-564.

Pringle, J.K., Hodgetts, D., Howell, J.A., Westerman, A.R., 2006. Virtual outcrop models of petroleum reservoir analogues-a review of the current state-of-the-art. First Break 24, 33-42.

Rabassa, J., Clapperton, C.M., 1990. Quaternary Glaciations of the southern andes. Quat. Sci. Rev. 9, 153-174.

Rarity, F., van Lanen, X.M.T., Hodgetts, D., Gawthorpe, R.L., Wilson, P., Fabuel-Perez, I., Redfern, J., 2014. LiDAR-based digital outcrops for sedimentological analysis: workflows and techniques. In: In: Martinius, A.W., Howell, J.A., Good, T.R. (Eds.), Sediment-Body Geometry and Heterogeneity: Analogue Studies for Modelling the Subsurface 387. Geological Society of London, Special Publications, pp. 153-183.

Riba, O., 1976. Syntectonic unconformities of the Alto Cardener, Spanish pyrenees: a genetic interpretation. Sediment. Geol. 15, 213-233.

Richiano, S., Varela, A.N., D'Elía, L., Bilmes, A., Aguirre, M., 2012. Evolución paleoambiental de cordones litorales holocenos durante una caída del nivel del mar en la Bahía Samborombon, Buenos Aires, Argentina. Lat. Am. J. Sedimentol. Basin Anal. 19, 105-124.

Rittersbacher, A., Buckley, S.J., Howell, J.A., Hampson, G.J., Vallet, J., 2014. Helicopterbased laser scanning: a method for quantitative analysis of large-scale sedimentary architecture. Geol. Soc. Lond. Spec. Publ. 387, 185-202.

Ružić, I., Marović, I., Benac, Č., Ilić, S., 2014. Coastal cliff geometry derived from structure-from-motion photogrammetry at Stara Baška, Krk Island, Croatia. Geo Mar. Lett. 34, 555-565.

Sanz-Ablanedo, E., Ordóñez, C., Chandler, J.H., Rodríguez-Pérez, J.R., 2018. Accuracy of unmanned aerial vehicle (UAV) and SfM photogrammetry survey as a function of the number and location of ground control points used. Remote Sens. 10, 1-19.

Scordo, F., Seitz, C., Zilio, M.I., Melo, W.D., Piccolo, M.C., Perillo, G.M., 2017. Evolución de los recursos hídricos en el "Bajo de Sarmiento" (Patagonia Extra Andina): impactos naturales y antrópico. Anu. do Inst. Geociencias 40, 106-117.

Seitz, S., Curless, B., Diebel, J., Scharstein, D., Szeliski, R., 2006. A Comparison and Evaluation of Multi-View Stereo Reconstruction Algorithms, vol. 1. pp. 519-528.

Shaw, J.H., Novoa, E., Connors, C.D., 2004. Structural controls on growth stratigraphy in contractional fault-related folds. In: In: McClay, K.R. (Ed.), Thrust Tectonics and Hydrocarbon Systems, vol. 82. American Association of Petroleum Geologists Memoir, pp. 400-412.

Snavely, N., Seitz, S.M., Szeliski, R., 2006. Photo tourism: exploring photo collections in 3D. ACM Trans. Graph. 25, 835-846.

Snavely, N., Seitz, S.M., Szeliski, R., 2008. Modeling the world from internet photo collections. Int. J. Comput. Vis. 80, 189-210.

Spalletti, L., Matheos, S., Poiré, D., 1987. Sedimentology of the Holocene littoral ridge of Samborombón bay (central Buenos Aires province, Argentina). Quat. S. Am. Antarct. Peninsula 5, 11-132.

Spetsakis, M., Aloimonos, J.Y., 1991. A multi-frame approach to visual motion perception. Int. J. Comput. Vis. 6, 245-255.

Storti, F., Poblet, J., 1997. Growth stratal architectures associated to decollement folds and fault-propagation folds. Inferences on fold kinematics. Tectonophysics 282, 353-373.

Sturzenegger, M., Stead, D., 2009. Quantifying discontinuity orientation and persistence on high mountain rock slopes and large landslides using terrestrial remote sensing techniques. Nat. Hazards Earth Syst. Sci. 9, 267-287.

Suppe, J., Chou, G.T., Hook, S.C., 1992. Rates of folding and faulting determined from 
growth strata. Thrust Tecton. 1, 105-121.

Szeliski, R., Kang, S.B., 1994. Recovering 3D shape and motion from image streams using nonlinear least squares. J. Vis. Commun. Image Represent. 5, 10-28.

Tamura, T., 2012. Beach ridges and prograded beach deposits as palaeoenvironment records. Earth Sci. Rev. 114, 279-297.

Tonkin, T.N., Midgley, N.G., Graham, D.J., Labadz, J.C., 2014. The potential of small unmanned aircraft systems and structure-from-motion for topographic surveys: a test of emerging integrated approaches at Cwm Idwal, North Wales. Geomorphology 226, 35-43.

Vergés, J., Marzo, M., Muñoz, J., 2002. Growth strata in foreland settings. Sediment. Geol. 146, 1-9.

Violante, R.A., Parker, G., 2004. The post-last glacial maximum transgression in the de la Plata River and adjacent inner continental shelf, Argentina. Quat. Int. 114, 167-181.

Violante, R.A., Parker, G., Cavallotto, J., 2001. Evolución de las llanuras costeras del este bonaerense entre la bahía Samborombón y la laguna Mar Chiquita durante el
Holoceno. Rev. Asoc. Geol. Argent. 56, 51-66.

Weill, P., Tessier, B., Mouazé, D., Bonnot-Courtois, C., Norgeot, C., 2012. Shelly cheniers on a modern macrotidal flat (Mont- Saint-Michel bay, France) Internal architecture revealed by ground-penetrating radar. Sediment. Geol. 279, 173-186.

Westoby, M.J., Brasington, J., Glasser, N.F., Hambrey, M.J., Reynolds, J.M., 2012

"Structure-from-Motion" photogrammetry: a low-cost, effective tool for geoscience applications. Geomorphology 179, 300-314.

Wilson, R.W., McCaffrey, K.J.W., Jones, R.R., Clegg, P., Holdsworth, R.E., 2005. Digital mapping of Lofoten's faults. Geoscientist 15, 4-9.

Zecchin, M., Catuneanu, O., 2013. High-resolution sequence stratigraphy of clastic shelves I: units and bounding surfaces. Mar. Pet. Geol. 39, 1-25.

Zhou, G., Xie, M., 2009. Coastal 3-D morphological change analysis using LiDAR series data: a case study of Assateague island National seashore. J. Coast. Res. 252, $435-447$. 